\title{
Selenium Biofortification Impacts the Nutritive Value, Polyphenolic Content, and Bioactive Constitution of Variable Microgreens Genotypes
}

\author{
Antonio Pannico ${ }^{1}{ }^{\circledR}$, Christophe El-Nakhel ${ }^{1}{ }^{\circledR}$, Giulia Graziani ${ }^{2}{ }^{\circledR}$, Marios C. Kyriacou ${ }^{3}{ }^{\circledR}$, \\ Maria Giordano ${ }^{1}$ (D) Georgios A. Soteriou ${ }^{3}\left(\mathbb{D}\right.$, Armando Zarrelli ${ }^{4}$ (D), Alberto Ritieni ${ }^{2}$, \\ Stefania De Pascale ${ }^{1}(\mathbb{D})$ and Youssef Rouphael ${ }^{1, * \mathbb{D}}$ \\ 1 Department of Agricultural Sciences, University of Naples Federico II, 80055 Portici, Italy; \\ antonio.pannico@unina.it (A.P.); Nakhel_Christophe@hotmail.com (C.E.-N.); \\ maria.giordano@unina.it (M.G.); depascal@unina.it (S.D.P.) \\ 2 Department of Pharmacy, University of Naples Federico II, 80131 Naples, Italy; \\ giulia.graziani@unina.it (G.G.); alberto.ritieni@unina.it (A.R.) \\ 3 Department of Vegetable Crops, Agricultural Research Institute, 1516 Nicosia, Cyprus; \\ m.kyriacou@ari.gov.cy (M.C.K.); soteriou@ari.gov.cy (G.A.S.) \\ 4 Department of Chemical Sciences, University of Naples Federico II, 800126 Naples, Italy; zarrelli@unina.it \\ * Correspondence: youssef.rouphael@unina.it
}

Received: 29 February 2020; Accepted: 23 March 2020; Published: 25 March 2020

\begin{abstract}
Selenium (Se) is considered essential for human nutrition as it is involved in the metabolic pathway of selenoproteins and relevant biological functions. Microgreens, defined as tender immature greens, constitute an emerging functional food characterized by overall higher levels of phytonutrients than their mature counterparts. The nutraceutical value of microgreens can be further improved through Se biofortification, delivering Se-enriched foods and potentially an enhanced content of bioactive compounds. The current study defined the effect of sodium selenate applications at three concentrations $(0,8$, and $16 \mu \mathrm{M}$ Se) on the bioactive compounds and mineral content of coriander, green basil, purple basil, and tatsoi microgreens grown in soilless cultivation. Analytical emphasis was dedicated to the identification and quantification of polyphenols by UHPLC-Q-Orbitrap-HRMS, major carotenoids by HPLC-DAD, and macro micro-minerals by ICP-OES. Twenty-seven phenolic compounds were quantified, of which the most abundant were: Chlorogenic acid and rutin in coriander, caffeic acid hexoside and kaempferol-3-O(caffeoyl) sophoroside-7-O-glucoside in tatsoi, and cichoric acid and rosmarinic acid in both green and purple basil. In coriander and tatsoi microgreens, the application of $16 \mu \mathrm{M}$ Se increased the total phenols content by $21 \%$ and $95 \%$, respectively; moreover, it improved the yield by $44 \%$ and $18 \%$, respectively. At the same Se dose, the bioactive value of coriander and tatsoi was enhanced by a significant increase in rutin $(33 \%)$ and kaempferol-3-O(feruloyl)sophoroside-7-O-glucoside (157\%), respectively, compared to the control. In green and purple basil microgreens, the $8 \mu \mathrm{M}$ Se application enhanced the lutein concentration by $7 \%$ and $19 \%$, respectively. The same application rate also increased the overall macroelements content by $35 \%$ and total polyphenols concentration by $32 \%$ but only in the green cultivar. The latter actually had a tripled chicoric acid content compared to the untreated control. All microgreen genotypes exhibited an increase in the Se content in response to the biofortification treatments, thereby satisfying the recommended daily allowance for Se (RDA-Se) from $20 \%$ to $133 \%$. The optimal Se dose that guarantees the effectiveness of Se biofortification and improves the content of bioactive compounds was $16 \mu \mathrm{M}$ in coriander and tatsoi, and $8 \mu \mathrm{M}$ in green and purple basil.
\end{abstract}

Keywords: coriander; green and purple basil; tatsoi; carotenoids; phenolic compounds; Orbitrap LC-MS/MS; sodium selenite; RDA; hidden hunger; dietary supplements 


\section{Introduction}

Microgreens have recently increased in popularity by earning the title of "functional food" or "superfood" [1,2]. They are defined as tender immature greens produced from seedlings of vegetables, grains, herbs, and wild species, harvested at soil level upon the appearance of a pair of first true leaves, which usually occurs within 7-21 days from sowing, depending on the species [3,4]. Microgreens contain higher levels of phytonutrients and secondary metabolites, such as microelements, carotenoids, and phenolic compounds, than their mature-leaf counterparts $[5,6]$. Interestingly, the demand for microgreens is increasing both in response to the intrinsic characteristics of the product (unique intense flavor, delicate texture, vivid colors) and due to the influence of new gastronomic trends sponsored by star chefs [7], especially for their nutraceutical value and putative beneficial effects on human health $[2,8]$. The nutraceutical value of microgreens may be further enhanced through biofortification with micronutrients. Selenium (Se) applications have been shown to have the dual effect of both enriching food with an essential microelement and increasing the overall content of bioactive compounds in microgreens [9,10].

Selenium is deemed essential for mammal nutrition as it is involved in the metabolic pathway of selenoproteins, selenoenzymes, and thyroid hormones, with fundamental biological functions [11]. Human micronutrient deficiency, also known as "hidden hunger", affects more than a billion people in the world [12], especially in areas with soils containing low levels of these trace elements or chemical-physical characteristics that limit their bioavailability [13]. Se deficiency leads to serious human disorders, such as heart diseases, viral infections, hyperthyroidism, diabetes, Keshan disease, and cancer [14-16]. These illnesses are most prevalent in developing countries, where the recommended dietary allowance (RDA) of Se $\left(55 \mu \mathrm{g} \mathrm{day}^{-1}\right)$ is not easily reached [17]. Additionally, Se supplementation with up to $400 \mu \mathrm{g}$ day $^{-1}$ has proven beneficial toward reducing the risk of certain types of cancer (i.e., colon, lung, and prostate cancer) in developed countries [18,19].

Opinions about selenium's role in higher plants diverge between being considered as a non-essential element $[16,20]$, or defined as beneficial [21,22]. Selenium application at low doses improves tolerance to oxidative stress, delays senescence, and stimulates yield, as demonstrated in several previous studies $[23,24]$. Selenium enhances the activity of antioxidant enzymes, such as lipoxygenase, catalase, ascorbate, and glutathione peroxidase, which in turn elicit the synthesis of secondary metabolites, including carotenoids, phenols, flavonoids, and vitamins $[10,25,26]$. Plants assimilate Se mainly in the form of selenate or selenite, the former being transported actively by sulphate transporters [27], while the latter is taken up via phosphate transporters [28]. However, compared to selenate, selenite is less soluble, more phytotoxic, and more difficult to transport and accumulate in plant tissues; for this reason, the selenate form is preferred for biofortification $[29,30]$. In any case, selenium at high concentrations depresses plant growth by interfering with the sulfur metabolic pathway. Indeed, Se phytotoxicity is mainly due to the incorporation of selenocysteines and selenomethionines, which replace their plant sulfur protein analogues [31].

Among the various biofortification techniques, Se application in the nutrient solution of soilless cultivation systems (SCSs) is certainly the most efficient solution [32,33]. In SCSs, eustress (i.e., positive stress) can be applied more reliably through accurate management of the composition and concentration of the nutrient solution $[33,34]$. By adopting such a technique, Se spread in the environment is minimized and Se assimilation is maximized by the absence of soil interactions; moreover, the constant root exposure to the nutrient solution affords the application of reduced Se rates, facilitates more effective standardization of food quality, and guarantees the safety of the food product offered to the consumer [32,33].

Although many Se biofortification studies have covered a wide range of cereal and vegetable crops, including wheat [35], rice [36], tomato [37], potato [38], beans [39], pea [40], endive [41], broccoli [42], rocket [27], lettuce [43], garlic [44], and shallot [45], the biofortification of microgreens with selenium has been poorly studied, aside from a few works on buckwheat [46], wheat [10], and basil [9]. Nevertheless, the effect of Se biofortification on the phenolic profile of microgreens has never been investigated. On 
the other hand, in a recent work where the phytochemical composition of 13 microgreens genotypes belonging to 5 botanical families was assessed, it was highlighted that coriander, basil, and tatsoi had the highest content of phenolic compounds [2].

Taking these findings into consideration, the effect of Se applications at three different concentrations was evaluated in the present study on coriander, green basil, purple basil, and tatsoi microgreens grown in SCS. The aim of the work was to illustrate Se accumulation in microgreens and identify the Se dose that enhances the nutraceutical characteristics of the product in terms of the mineral content, carotenoids, and phenolic compounds, without deleterious effects on yield.

\section{Materials and Methods}

\subsection{Plant Material and Growth Chamber Conditions}

Four microgreens genotypes were chosen to assess their bioactive compounds and mineral content: Coriander (Coriandrum sativum L.; Micro Splits, CN Seeds Ltd., Pymoor, Ely, Cambrigeshire, UK), two different basil cultivars (green basil, Ocimum basilicum L.; Orto del Sole, Bari, Puglia, Italy and purple basil, Ocimum basilicum L.; Condor Seed Production, Yuma, AZ, USA), and tatsoi (Brassica rapa L. subsp. narinosa; Condor Seed Production, Yuma, AZ, USA).

The experiment was carried out at the Department of Agricultural Sciences of University of Naples Federico II, Portici, Italy in a growth chamber (KBP-6395F, Termaks, Bergen, Norway) equipped with an Light-Emitting Diode (LED) panel unit (K5 Series XL750, Kind LED, Santa Rosa, CA, USA) with an emission wavelength range of $400-700 \mathrm{~nm}$. The microgreens were sown on a capillary mat (Aquamat capillary matting, Premier Netting, Norfolk, UK) laid in plastic trays $(14 \times 19 \times 6 \mathrm{~cm}: \mathrm{W} \times \mathrm{L} \times \mathrm{D})$. The sowing density was 4 seeds $\mathrm{cm}^{-2}$ for coriander and 7 seeds $\mathrm{cm}^{-2}$ for tatsoi, green, and purple basil; harvest was performed 12 days after sowing (DAS) for tatsoi and 19 DAS for coriander, green, and purple basil.

The LED panel positioned inside the chamber ensured a homogeneous distribution of light (300 $\pm 10 \mu \mathrm{mol} \mathrm{m}{ }^{-2} \mathrm{~s}^{-1}$ at the canopy level) over the entire shelf surface $\left(0.4 \mathrm{~m}^{2}\right)$. Nevertheless, the trays were randomly rotated every $24 \mathrm{~h}$ in order to improve the uniformity of light intensity at the canopy level. The photosynthetic photon flux density (PPFD) and the light spectra were regulated at the canopy level using a spectral radiometer (MSC15, Gigahertz-Optik, Turkenfeld, Germany). A day/night temperature and relative air humidity of $24 / 18{ }^{\circ} \mathrm{C}$ and $75 / 85 \%$, respectively, were established with a $16 / 8 \mathrm{~h}$ photoperiod.

Microgreens were fertigated with a modified quarter-strength Hoagland nutrient solution prepared with distilled water containing: $2.0 \mathrm{mM}$ nitrate, $0.25 \mathrm{mM}$ sulfur, $0.20 \mathrm{mM}$ phosphorus, $0.62 \mathrm{mM}$ potassium, $0.75 \mathrm{mM}$ calcium, $0.17 \mathrm{mM}$ magnesium, $0.25 \mathrm{mM}$ ammonium, $20 \mu \mathrm{M}$ iron, $9 \mu \mathrm{M}$ manganese, $0.3 \mu \mathrm{M}$ copper, $1.6 \mu \mathrm{M}$ zinc, $20 \mu \mathrm{M}$ boron, and $0.3 \mu \mathrm{M}$ molybdenum, with an electrical conductivity (EC) of $0.35 \mathrm{dS} \mathrm{m}^{-1}$ and a $\mathrm{pH}$ of 6.0. The nutrient solution was supplied on a daily basis onto the substrate using a laboratory beaker.

The test was conducted according to a randomized design in a factorial arrangement $(3 \times 4)$, with three concentrations $(0,8$, or $16 \mu \mathrm{M})$ of sodium selenate (Sigma-Aldrich, St. Louis, MO, USA) in the nutrient solution and four microgreen genotypes (coriander, green basil, purple basil, and tatsoi), with three replicates.

\subsection{Plant Material and Growth Chamber Conditions}

All microgreens were collected at the appearance of the second true leaf by cutting the seedlings at the substrate level with sterilized scissors. The collected material was weighed to determine the fresh yield, expressed as $\mathrm{kg}$ fresh weight (fw) per square meter. Fresh samples of microgreens randomly selected from each tray were instantly frozen in liquid nitrogen and stored at $-80{ }^{\circ} \mathrm{C}$ before lyophilization in a freeze drier (Christ, Alpha 1-4, Osterode, Germany), in order to be used for mineral and phytochemical analyses. 


\subsection{Dry Matter and Nitrate Content Analysis}

Dry weight (dw) was measured on an analytical balance (Denver instruments, Denver, CO, USA) following lyophilization until a constant weight was reached. Dry matter content was determined in triplicate based on the official method 934.01 of the Association of Official Analytical Chemists, and expressed as a percentage. The dry samples were finely ground in a Wiley Mill (MF 10.1, IKA, Staufen, Germany) to be utilized for chemical analysis. Nitrate content was analyzed by ion chromatography (ICS-3000, Dionex, Sunnyvale, CA, USA) as previously described by Kyriacou et al. [2]. Separation was achieved in gradient mode on an AS11-HC analytical column $(4 \times 250 \mathrm{~mm}$, Dionex, Sunnyvale, CA, USA) equipped with an AG11-HC pre-column $(4 \times 50 \mathrm{~mm}$, Dionex, Sunnyvale, CA, USA) and a dynamically regenerated suppressor DRS600 (Dionex, Sunnyvale, CA, USA). Results were expressed as $\mathrm{mg} \mathrm{kg}^{-1}$ fresh weight according to the dry matter content of each sample.

\subsection{Mineral Analysis by ICP-OES and Consumer Safety of Se-Enriched Microgreens}

Macro ( $\mathrm{P}, \mathrm{K}, \mathrm{Ca}, \mathrm{Mg}$, and $\mathrm{Na}$ ) and trace (Fe, $\mathrm{Zn}, \mathrm{Mn}$, and Se) elements in microgreen samples were measured using an inductively coupled plasma mass spectrometer (ICP-OES Spectroblue, Spectro Ametek, Berwyn, PA, USA). A full description of the method used for the heavy metal analyses in leaf samples appears in Volpe et al. [47]. Briefly, $1000 \mathrm{mg}$ of lyophilized microgreens were fully digested in a microwave digestion system (MLS-1200 Microwave Laboratory Systems, Milestone, Shelton, CT, USA) with the addition of a mixture of $\mathrm{HNO}_{3}(65 \%)$ and $\mathrm{HCl}(37 \%)(9: 3, v / v ; 12 \mathrm{~mL})$, and the resulting solutions were transferred to $100-\mathrm{mL}$ volumetric flasks and diluted to the fixed volume (50 mL) with ultrapure water (Milli-Q, Merck Millipore, Darmstadt, Germany). The calibration curve was prepared using a working standard solution with concentrations ranging from 1.0 to $100 \mu \mathrm{g} \mathrm{L}{ }^{-1}$ for all non-alkaline elements ( $\mathrm{Fe}, \mathrm{Zn}, \mathrm{Mn}$, and Se) and with concentrations ranging from $100 \mu \mathrm{g} \mathrm{L}^{-1}$ to $10 \mathrm{mg} \mathrm{L}^{-1}$ for all alkaline elements $(\mathrm{K}, \mathrm{Ca}, \mathrm{Mg}$, and $\mathrm{Na})$. The results were expressed as $\mathrm{mg} \mathrm{g}^{-1} \mathrm{dw}(\mathrm{P}$, $\mathrm{K}, \mathrm{Ca}, \mathrm{Mg}$, and $\mathrm{Na}$ ) and $\mu \mathrm{g} \mathrm{g}^{-1} \mathrm{dw}(\mathrm{Fe}, \mathrm{Zn}, \mathrm{Mn}$, and Se).

The green vegetables' hazard quotient $\left(\mathrm{HQ}_{\mathrm{gv}}\right)$ of selenium was calculated according to the United States Environmental Protection Agency (USEPA) Protocol [48] using the following formula:

$$
\mathrm{HQ}_{\mathrm{gv}}=(\mathrm{ADD} / \mathrm{RfD}),
$$

where ADD is the average daily dose of selenium $\left(\mu \mathrm{g} \mathrm{Se} \mathrm{day}{ }^{-1}\right)$ and RfD represents the recommended dietary tolerable upper intake level of selenium $\left(\mu \mathrm{g}\right.$ Se day ${ }^{-1}$ ) assessed as equal to $400 \mu \mathrm{g} \mathrm{day}^{-1}$ [17], referring to the risk to human health of a 70-kg adult resulting from Se intake through the consumption of a 10-g portion of fresh microgreens. HQgv values below 1.00 indicate that the vegetable is safe for consumption by human beings.

\subsection{Separation and Quantification of Carotenoids by HPLC-DAD}

Lutein and $\beta$-carotene were extracted from $100 \mathrm{mg}$ of lyophilized sample suspended in $6 \mathrm{~mL}$ of ethanol containing $0.1 \%$ Butylated hydroxytoluene (BHT), according to the procedure described by Kyriacou et al. [2]. Carotenoids' separation was achieved in gradient mode using a Shimadzu HPLC (Model LC 10, Shimadzu, Osaka, Japan) equipped with a reverse phase column $(250 \times 4.6 \mathrm{~mm}, 5 \mu \mathrm{m}$ Gemini C18, Phenomenex, Torrance, CA, USA). The injection volume was $20 \mu \mathrm{L}$ while the total runtime was $25 \mathrm{~min}$. The quantification was carried out by measuring the absorbance at $450 \mathrm{~nm}$, against linear calibration curves built with lutein and $\beta$-carotene external standards (ranging from 5 to $100 \mu \mathrm{g} \mathrm{mL}^{-1}$ ) containing not less than six concentration levels. The results were expressed as $\mathrm{mg} \mathrm{kg}^{-1} \mathrm{dw}$.

\subsection{Extraction and Analysis of Polyphenols by UHPLC-Q-Orbitrap HRMS}

Polyphenols were extracted from $100 \mathrm{mg}$ of lyophilized microgreens following the methods detailed in Kyriacou et al. [2]. Polyphenols were quantified and separated using an UHPLC system (Thermo Fisher Scientific, Waltham, MA, USA) equipped with a quaternary pump (Ultimate 3000, 
Dionex, Sunnyvale, CA, USA) and a thermostated column $(100 \times 2.1 \mathrm{~mm}$, Kinetex $1.7 \mu \mathrm{m}$ biphenyl, Phenomenex, Torrance, CA, USA). Mass spectrometry analysis was facilitated by a Q Exactive Orbitrap LC-MS/MS (Thermo Fisher Scientific, Waltham, MA, USA). The acquisition of polyphenolic compounds was performed according to Kyriacou et al. [2], where the protocol is fully detailed. The calibration and accuracy of the equipment was monitored by using a reference standard mixture (Thermo Fisher Scientific, Waltham, MA, USA). Data analysis and processing were developed with the Xcalibur software, version 3.0.63 (Thermo Fisher Scientific, Waltham, MA, USA).

\subsection{Statistics of Experimental Data}

Data were initially subjected to a two-way analysis of variance (ANOVA). Interactions were further addressed through genotype-specific one-way ANOVA and treatment means were compared using Duncan's multiple range test performed at $p \leq 0.05$ using the SPSS 20 software package (IBM, Armonk, NY, USA).

\section{Results and Discussion}

The initial two-way ANOVA of genotype vs. Se treatment revealed widespread interaction for almost all variables examined (Table 1), reflecting the differential capacity of the various microgreen genotypes for Se uptake. Therefore, further one-way ANOVA and mean comparisons were performed within each genotype with respect to the Se treatments.

\subsection{Fresh Biomass Yield and Dry Matter Content}

Tatsoi was the earliest genotype achieving harvest maturity (12 DAS), while coriander, green, and purple basil were harvested exactly a week later (19 DAS). The growth period of the respective microgreens is comparable with that found in a previous work on the same genotype harvested at the second true leaf stage, in which tatsoi was found to be harvest ready earlier than coriander, green, and purple basil [2]. Yield varied significantly between genotypes (Figure 1), with the highest fresh biomass achieved by tatsoi (1.19-1.41 $\left.\mathrm{kg} \mathrm{m}^{-2}\right)$, followed by purple basil (1.20-1.23 $\left.\mathrm{kg} \mathrm{m}^{-2}\right)$, coriander $\left(0.84-1.21 \mathrm{~kg} \mathrm{~m}^{-2}\right)$, and green basil $\left(0.85-0.90 \mathrm{~kg} \mathrm{~m}^{-2}\right)$. On the other hand, the dry matter content was highest in coriander (12.8-14.0\%), followed by green basil (10.1-11.9\%), purple basil (8.6-9.2\%), and tatsoi (8.0-8.3\%; Figure 1B). Regardless of the genotype, yield was overall lower than previously found by Kyriacou et al. [2] on the same microgreen genotypes sown at an equal seed density on peat-based substrate. This response is attributable to the different growth substrates used; the commercial peat-based media provide an optimal aeration-moisture root environment and a more efficient supply of nutrients, promoting faster growth than the chemically inert capillary mat presently used. In our study, no toxic effect of Se addition on the fresh yield of microgreens occurred; by contrast, the dry matter content observed in our experiment was overall higher than that reported by Kyriacou et al. [2], owing to the slower growth sustained on the capillary mat. 
Table 1. Two-way analysis of variance (ANOVA) of all the analyzed variables of the four microgreen genotypes grown in a growth chamber on capillary mat substrate under three Se concentrations applied in the nutrient solution.

\begin{tabular}{|c|c|c|c|c|c|c|c|}
\hline \multirow{2}{*}{ Variables } & \multicolumn{3}{|c|}{ Source of Variance } & \multirow{2}{*}{ Variables } & \multicolumn{3}{|c|}{ Source of Variance } \\
\hline & Genotype (G) & Selenium (S) & $\mathrm{G} \times \mathrm{S}$ & & Genotype (G) & Selenium (S) & $\mathrm{G} \times \mathrm{S}$ \\
\hline Fresh yield & $* * *$ & $* * *$ & $* * *$ & kaempferol-3-O(caffeoyl)sophoroside-7-O-glucoside & $* * *$ & $* * *$ & $* * *$ \\
\hline Dry matter & $* * *$ & ns & $* * *$ & isorhamnetin-3-gentiobioside & na & $* * *$ & na \\
\hline Nitrate & $* * *$ & *** & ns & kaempferol-3-O-(coumaroyl)soph-7-O-glucoside & $* * *$ & $* * *$ & $* * *$ \\
\hline $\mathrm{P}$ & $* * *$ & $* * *$ & $* * *$ & luteolin-7-O-glucoside & $* * *$ & ns & $* * *$ \\
\hline $\mathrm{K}$ & $* * *$ & $* * *$ & $* * *$ & apigenin-malonil-glucoside & $* * *$ & $* * *$ & $* * *$ \\
\hline $\mathrm{Ca}$ & $* * *$ & $* * *$ & $* * *$ & kaempferol-3-O(feruoyll)sophoroside-7-O-glucoside & $* * *$ & $* * *$ & $* * *$ \\
\hline $\mathrm{Mg}$ & $* * *$ & $* * *$ & $* * *$ & coumaroyl quinic acid & $* * *$ & $* * *$ & $* * *$ \\
\hline $\mathrm{Na}$ & $* * *$ & $* * *$ & $* * *$ & rutin & $* * *$ & $* * *$ & $* * *$ \\
\hline $\mathrm{Fe}$ & $* * *$ & $* * *$ & $* * *$ & apigenin-7-O-rutinoside & $* * *$ & $* * *$ & $* * *$ \\
\hline $\mathrm{Zn}$ & $* * *$ & $* * *$ & $* * *$ & quercetin-3-O-glucoside & $* * *$ & $* * *$ & $* * *$ \\
\hline $\mathrm{Mn}$ & $* * *$ & ** & $* * *$ & feruloyl quinic acid & $* * *$ & $* * *$ & $* * *$ \\
\hline Se & $* * *$ & $* * *$ & $* * *$ & rosmarinic acid & $* * *$ & * & $* * *$ \\
\hline Se intake & $* * *$ & $* * *$ & $* * *$ & cirsiliol & $* * *$ & $* * *$ & $* * *$ \\
\hline RDA-Se & $* * *$ & $* * *$ & $* * *$ & ferulic acid & $* * *$ & $* * *$ & $* * *$ \\
\hline HQgv & $* * *$ & $* * *$ & $* * *$ & luteolin-3-O-rutinoside & $* * *$ & $* * *$ & $* * *$ \\
\hline lutein & $* * *$ & $* * *$ & $* * *$ & kaempferol-7-O-glucoside & $* * *$ & $* * *$ & $* * *$ \\
\hline$\beta$-carotene & $* * *$ & $* * *$ & $* * *$ & dicaffeoylquinic acid & $* * *$ & $* * *$ & $* * *$ \\
\hline cichoric acid & $* * *$ & $* * *$ & $* * *$ & kaempferol-3-O-rutinoside & $* * *$ & $* * *$ & $* * *$ \\
\hline chlorogenic acid & $* * *$ & ns & ns & quercetin-rhamnoside & $* * *$ & ns & ns \\
\hline caffeic acid & $* * *$ & $* * *$ & $* * *$ & luteolin-malonil-hexose & $\mathrm{ns}$ & ns & ns \\
\hline kaempferol-3-O-sophoroside-7-O-glucoside & na & $* * *$ & na & apigenin-7-rhamnoside-4-rutinoside & na & $* * *$ & na \\
\hline quercetin-sophoroside & $* * *$ & $* * *$ & $* * *$ & apigenin-7-O-glucoside & $* * *$ & $* * *$ & $* * *$ \\
\hline caffeic acid hexoside isomers & $* * *$ & $* * *$ & $* * *$ & & & & \\
\hline 2-xylosylvitexin & $* * *$ & ns & ns & Total polyphenols & $* * *$ & ns & $* * *$ \\
\hline
\end{tabular}




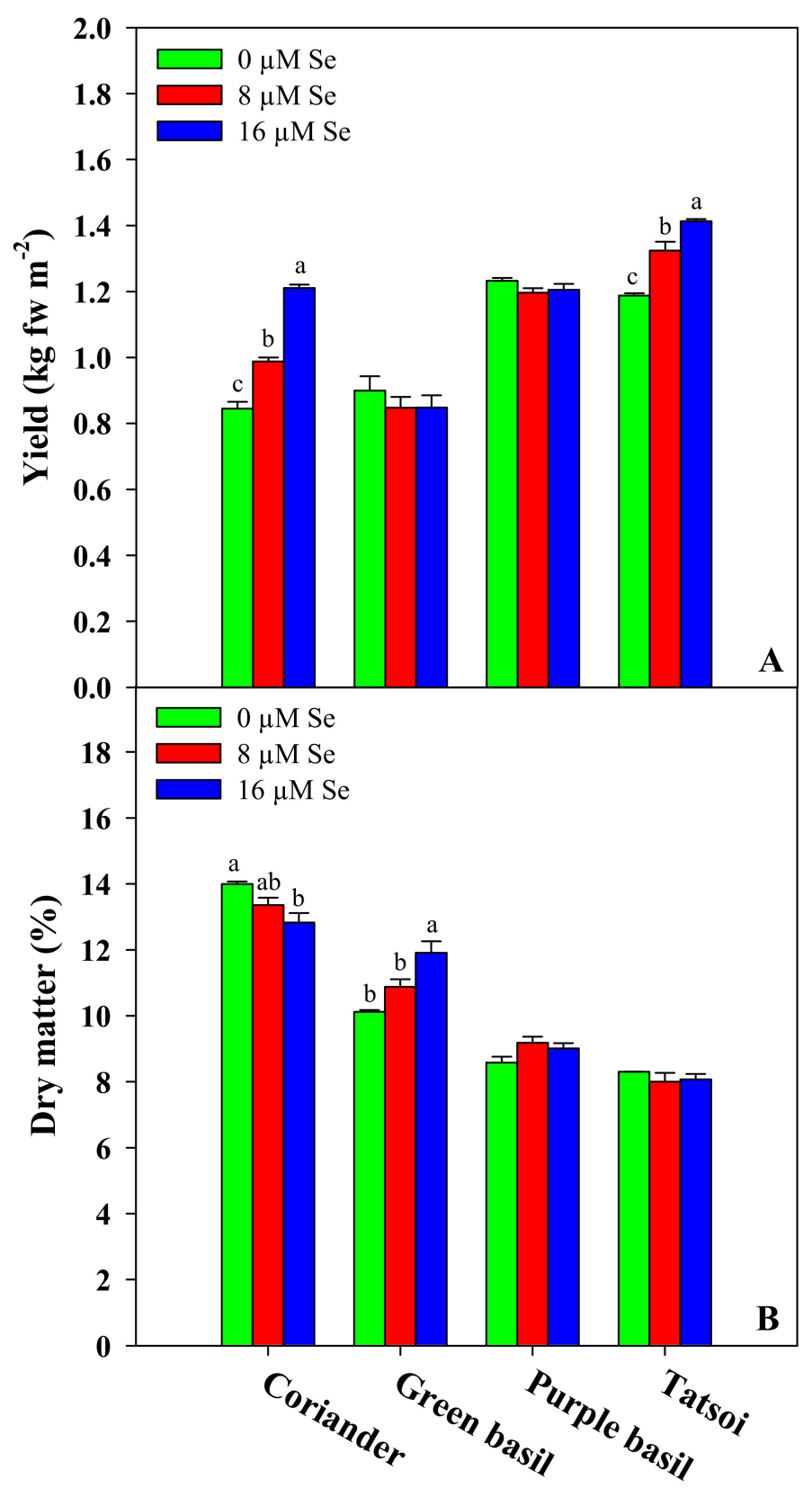

Figure 1. Effects of the selenium concentration on the fresh yield (A) and dry matter (B) of four microgreen genotypes grown in a growth chamber on a capillary mat substrate under three Se concentrations applied in the nutrient solution. The different letters $(a-c)$ above the bars indicate significant mean differences within each genotype according to Duncan's multiple range tests $(p \leq 0.05)$. The absence of letters denotes the absence of significant differences. The values are the means of three replicates. Vertical bars indicate $\pm \mathrm{SE}$ of means.

Selenium treatments significantly improved the yield of tatsoi and coriander. In particular, the addition of Se at 8 and $16 \mu \mathrm{M}$ increased the fresh biomass of tatsoi by $11 \%$ and $18 \%$, respectively, and increased the coriander fresh biomass by $18 \%$ and $44 \%$, respectively (Figure $1 \mathrm{~A}$ ). No significant effect of Se treatment was observed on the fresh yield of green and purple basil (Figure 1A). Nevertheless, in green basil, the dry matter content increased by $8 \%$ and $18 \%$ at the 8 and $16 \mu \mathrm{M}$ Se rates, respectively, while an opposite effect was observed in coriander at the $16 \mu \mathrm{M}$ Se treatment with a reduction of $8 \%$ compared to the control. However, no significant Se effect on dry matter was found in purple basil and tatsoi. No deleterious effect of Se treatments was observed on the fresh yield of the four 
microgreen genotypes studied. The non-significant effect on yield observed in green and purple basil was in agreement with previous studies on Se-biofortified microgreens [9] and mature plants [26] of basil. On the other hand, the beneficial Se effect found on the yield of coriander and tatsoi was consistent with the growth-promoting response to low Se doses demonstrated in previous works on rice sprouts [49] and mature plants of Indian mustard [50], ryegrass [51], spinach [52], and lettuce [53]. It was demonstrated that Se at low concentrations can stimulate plant growth, enhance photosynthesis, and support the homeostasis of essential nutrients [54]. In addition, low-Se-dose treatments work as a stress modulator that inhibits the accumulation of Reactive Oxygen Species (ROS) during stress by acting as an antioxidant [55]. On the contrary, at high concentrations, selenium acts as a pro-oxidant, inducing an increase in ROS and lipid peroxidation [56,57]. Considering that the Se response is dose as well as genotype dependent, further studies should focus on clarifying the interaction between genotype and application dose, in order to identify the combination that guarantees an optimal balance between yield and biofortification in targeted species/genotypes.

\subsection{Nitrate Content and Mineral Composition}

One of the most critical factors related to the consumption of fresh leafy vegetables is certainly associated with their nitrate content. Indeed, high nitrate levels can be harmful to human health, causing serious physiological disorders, such as methemoglobinemia and blue baby syndrome [58]. The maximum limit for the nitrate concentration established by the Commission Regulation (EU) No $1258 / 2011$ [59] for the commercialization of fresh mature vegetables ranges from 3000 to $7000 \mathrm{mg} \mathrm{kg}^{-1}$ fw depending on the species (lettuce, spinach, and rocket) and the harvest season (summer or winter). In the present work, the nitrate content was significantly different among microgreen genotypes; in particular, purple basil was the highest nitrate accumulator (451.2-539.9 $\mathrm{mg} \mathrm{kg}^{-1} \mathrm{fw}$ ) followed by green basil (84.1-216.1 $\left.\mathrm{mg} \mathrm{kg}^{-1} \mathrm{fw}\right)$, tatsoi (63.7-80.6 $\left.\mathrm{mg} \mathrm{kg}^{-1} \mathrm{fw}\right)$, and coriander (9.5-18.5 $\mathrm{mg} \mathrm{kg}^{-1} \mathrm{fw}$ ) (Table 2). In any case, although microgreens have not yet been regulated regarding nitrate content, the levels found were far below the limits established by the EU regulation for mature lettuce, spinach, and rocket salad crops. The microgreen nitrate content observed in our experiment was overall much lower than the values (2549-4032 $\mathrm{mg} \mathrm{kg}^{-1} \mathrm{fw}$ ) previously reported by Kyriacou et al. [2]. This remarkable difference could be related to the higher content and release of nitrate from the peat-based substrate used in the work of Kyriacou et al. [2] compared to the chemically inert capillary mat adopted in the current experiment. Regardless of the genotypes, selenium applications have significantly affected the nitrate content of microgreens (Table 2). Overall, Se applications at both doses demonstrated an average $24 \%$ reduction of nitrate levels in all four genotypes compared to the untreated control. This important result could be associated with the antagonistic effect of selenate exerted on nitrate anions [60]. In addition, Nowak and co-authors [61] demonstrated that Se enhanced nitrate reductase activity in plants, leading to a decrease of the foliar nitrate content. Our data are consistent with the nitrate reduction observed in previous works on lettuce plants treated with selenate at different concentrations [43,62,63].

Major ( $\mathrm{P}$ and $\mathrm{K})$, secondary ( $\mathrm{Ca}$ and $\mathrm{Mg}$ ), and trace ( $\mathrm{Na}, \mathrm{Fe}, \mathrm{Zn}$, and $\mathrm{Mn}$ ) minerals are essential for human health as components of our skeletal structure and are essential for countless body processes, acting as co-factors for several enzymes [64]. Among the four microgreen genotypes examined, significant differences were observed relative to the concentrations of macro $(\mathrm{P}, \mathrm{K}, \mathrm{Ca}, \mathrm{Mg}$, and $\mathrm{Na})$ and micro (Fe, $\mathrm{Zn}$, and $\mathrm{Mn}$ ) nutrients (Table 2). Among all genotypes, the most abundant macroelement was $\mathrm{K}$, ranging from 2.9 to $13.0 \mathrm{mg} \mathrm{g}^{-1} \mathrm{dw}$, followed by Ca (3.2-10.6 $\left.\mathrm{mg} \mathrm{g}^{-1} \mathrm{dw}\right), \mathrm{P}\left(1.9-4.5 \mathrm{mg} \mathrm{g}^{-1} \mathrm{dw}\right.$ ), $\mathrm{Mg}\left(2.1-3.6 \mathrm{mg} \mathrm{g}^{-1} \mathrm{dw}\right)$, and $\mathrm{Na}\left(0.4-0.8 \mathrm{mg} \mathrm{g}^{-1} \mathrm{dw}\right)$, whereas the most representative microelements were Fe (20.5-57.2 $\left.\mu \mathrm{g} \mathrm{g}^{-1} \mathrm{dw}\right), \mathrm{Zn}\left(23.2-64.6 \mu \mathrm{g} \mathrm{g}{ }^{-1} \mathrm{dw}\right)$, and Mn (6.6-46.1 $\left.\mu \mathrm{g} \mathrm{g}^{-1} \mathrm{dw}\right)$ (Table 2). In general, the macro and microelement profiles of microgreens tested is fully comparable to the trend described in previous works on microgreens; however, the overall mineral content is slightly lower than the microgreens grown on peat-based substrate $[2,65]$. 
Table 2. Nitrate, phosphorus (P), potassium (K), calcium (Ca), magnesium (Mg), sodium ( $\mathrm{Na})$, iron (Fe), zinc ( $\mathrm{Zn})$, and manganese (Mn) concentrations of four microgreen genotypes grown in a growth chamber on a capillary mat substrate under three Se concentrations applied in the nutrient solution.

\begin{tabular}{|c|c|c|c|c|c|c|c|c|c|c|}
\hline Genotype & Selenium & $\begin{array}{c}\text { Nitrate } \\
\left(\mathrm{mg} \mathrm{kg}^{-1} \mathrm{fw}\right)\end{array}$ & $\begin{array}{c}P \\
\left(\mathrm{mg} \mathrm{g}^{-1} \mathrm{dw}\right)\end{array}$ & $\begin{array}{c}\mathrm{K} \\
\left(\mathrm{mg} \mathrm{g}^{-1} \mathrm{dw}\right)\end{array}$ & $\begin{array}{c}\text { Ca } \\
\left(\mathrm{mg} \mathrm{g}^{-1} \mathrm{dw}\right)\end{array}$ & $\begin{array}{c}\mathrm{Mg} \\
\left(\mathrm{mg} \mathrm{g}^{-1} \mathrm{dw}\right)\end{array}$ & $\begin{array}{c}\mathrm{Na} \\
\left(\mathrm{mg} \mathrm{g}^{-1} \mathrm{dw}\right)\end{array}$ & $\begin{array}{c}F e \\
\left(\mu g^{-1} d w\right)\end{array}$ & $\begin{array}{c}\mathrm{Zn} \\
\left(\mu \mathrm{g} \mathrm{g}^{-1} \mathrm{dw}\right)\end{array}$ & $\begin{array}{c}\mathrm{Mn} \\
\left(\mu \mathrm{g} \mathrm{g}^{-1} \mathrm{dw}\right)\end{array}$ \\
\hline \multirow{3}{*}{ Coriander } & $0 \mu \mathrm{M}$ & $3.5 \pm 2.75 a$ & $.04 \pm 0.08 \mathrm{c}$ & $7.23 \pm 0.23 b$ & $3.15 \pm 0.04 b$ & $2.17 \pm 0.08 b$ & $0.61 \pm 0.01 \mathrm{~b}$ & $20.45 \pm 0.06 c$ & $23.18 \pm 0.39 c$ & $6.61 \pm 0.17 b$ \\
\hline & $8 \mu \mathrm{M}$ & $\pm 0.43 b$ & $9 \pm 0.04 b$ & $8.09 \pm 0.39 \mathrm{ab}$ & $41 \pm 0.14 b$ & $2.36 \pm 0.03 \mathrm{ab}$ & $.63 \pm 0.03 b$ & $22.28 \pm 0.58 b$ & $27.22 \pm 0.96 b$ & $7.64 \pm 0.59 \mathrm{~b}$ \\
\hline & $16 \mu \mathrm{M}$ & $9.5 \pm 0.58 \mathrm{~b}$ & $3.72 \pm 0.03 \mathrm{a}$ & $9.27 \pm 0.43 \mathrm{a}$ & $4.15 \pm 0.02 \mathrm{a}$ & $2.58 \pm 0.09 \mathrm{a}$ & $0.72 \pm 0.01 \mathrm{a}$ & $25.42 \pm 0.08 \mathrm{a}$ & $36.79 \pm 0.21 \mathrm{a}$ & $9.30 \pm 0.05 \mathrm{a}$ \\
\hline \multirow{4}{*}{ Green basil } & Significance & * & $* * *$ & * & $* * *$ & * & * & $* * *$ & $* * *$ & $* *$ \\
\hline & $0 \mu \mathrm{M}$ & $216.1 \pm 8.34 \mathrm{a}$ & $1.87 \pm 0.12 c$ & $9.19 \pm 0.22 b$ & $8.16 \pm 0.49 b$ & $2.15 \pm 0.03 b$ & $0.49 \pm 0.01 b$ & $36.73 \pm 0.27 \mathrm{a}$ & $64.56 \pm 4.52 \mathrm{a}$ & $13.18 \pm 0.39 c$ \\
\hline & $8 \mu \mathrm{M}$ & $\mathrm{b}$ & $5 \pm 0$ & $12.80 \pm 0.08 \mathrm{a}$ & $9.95 \pm 0.42 \mathrm{a}$ & $3.04 \pm$ & $0.54 \pm$ & $35.27 \pm$ & $7.88 \pm$ & 21.27 \\
\hline & $\begin{array}{c}16 \mu \mathrm{M} \\
\text { Significance }\end{array}$ & ${ }^{84.1} \pm 7.63 \mathrm{c}$ & $\underbrace{}_{* * *} .65 \mathrm{a}$ & $\underset{* * *}{12.90 \pm 0.16 \mathrm{a}}$ & $\begin{array}{c}10.62 \pm 0.54 \mathrm{a} \\
*\end{array}$ & $3.56 \pm 0.28 \mathrm{a}$ & $\begin{array}{c}0.56 \pm 0.01 \mathrm{a} \\
*\end{array}$ & $36.83 \pm 0.51 \mathrm{a}$ & $24.97 \pm 1.16 b$ & $22.85 \pm 0.45 \mathrm{a}$ \\
\hline \multirow[t]{2}{*}{ Purple basil } & $8 \mu \mathrm{M}$ & $\mathrm{b}$ & $4.12 \pm 0.03 \mathrm{a}$ & $13.03 \pm($ & $8.88 \pm 0$ & $3.29 \pm 0$ & $046+$ & $51.93=$ & $38.80=$ & $12.41 \pm 0.18 b$ \\
\hline & $\begin{array}{c}16 \mu \mathrm{M} \\
\text { Significance }\end{array}$ & $\begin{array}{c}453.3 \pm 19.8 \mathrm{~b} \\
*\end{array}$ & $\underset{* *}{4.34} \pm 0.11 \mathrm{a}$ & $\begin{array}{c}12.63 \pm 0.03 \mathrm{a} \\
*\end{array}$ & $\underset{* *}{9.44 \pm 0.08 \mathrm{a}}$ & $\begin{array}{c}3.36 \pm 0.07 \mathrm{a} \\
*\end{array}$ & $\underset{* * * *}{0.48} \pm 0.01 \mathrm{~b}$ & $\underset{* * *}{57.16 \pm 0.68 \mathrm{a}}$ & $\underset{* * *}{41.36 \pm 0.24 \mathrm{a}}$ & $13.32 \pm 0.25 \mathrm{a}$ \\
\hline \multirow{3}{*}{ Tatsoi } & $0 \mu \mathrm{M}$ & $80.6 \pm 2.98 \mathrm{a}$ & $4.48 \pm 0.22 \mathrm{a}$ & $4.11 \pm 0.19 \mathrm{a}$ & $4.42 \pm 0.08 \mathrm{a}$ & $3.33 \pm 0.20 \mathrm{a}$ & $0.75 \pm 0.02 \mathrm{a}$ & $52.56 \pm 3.30 \mathrm{a}$ & $43.22 \pm 1.81 \mathrm{a}$ & $46.06 \pm 2.40 \mathrm{a}$ \\
\hline & $8 \mu \mathrm{M}$ & $63.7 \pm 0.12 b$ & $3.44 \pm 0.06 b$ & $2.86 \pm 0.17 b$ & $2.85 \pm 0.27 b$ & $2.12 \pm 0.08 \mathrm{~b}$ & $0.39 \pm 0.02 c$ & $29.98 \pm 0.27 c$ & $34.75 \pm 0.16 c$ & $28.81 \pm 0.53 c$ \\
\hline & $\begin{array}{c}16 \mu \mathrm{M} \\
\text { Sionificance }\end{array}$ & $64.7 \pm 0.97 \mathrm{~b}$ & $3.84 \pm \underset{* *}{0.04 b}$ & $3.82 \pm 0.15 \mathrm{a}$ & $\underset{* *}{3.90 \pm 0.17 \mathrm{a}}$ & $\underset{* *}{2.56} \pm 0.10 \mathrm{~b}$ & $0.58 \pm \underset{* * *}{0.03 b}$ & $40.79 \pm \underset{* * *}{ } 1.61 \mathrm{~b}$ & $38.77 \pm 0.05 b$ & $35.03 \pm 1.46 \mathrm{~b}$ \\
\hline
\end{tabular}

ns, ${ }^{*}, * * * * *$ Non-significant or significant at $p \leq 0.05,0.01$, and 0.001 , respectively. Different letters within each column indicate significant mean differences within each genotype according

to Duncan's multiple range tests $(p \leq 0.05)$. All data are expressed as mean $\pm \mathrm{SE}, n=3$. 
In green basil, an increase of $63 \%$ and $95 \%$ of phosphorus, $39 \%$ and $40 \%$ of potassium, $22 \%$ and $30 \%$ of calcium, and $41 \%$ and $66 \%$ of magnesium was observed at doses of 8 and $16 \mu \mathrm{M}$ Se, respectively, in comparison to the control. Likewise, a significant rise of $18 \%$ and $25 \%$ of phosphorus, $17 \%$ and $14 \%$ of potassium, $22 \%$ and $29 \%$ of calcium, and $15 \%$ and $17 \%$ of magnesium was found in purple basil at doses of 8 and $16 \mu \mathrm{M}$ Se, respectively. In coriander, Se applications improved the concentration of $\mathrm{P}$ ( $15 \%$ and $22 \%$ at the 8 and $16 \mu \mathrm{M}$ Se doses, respectively), K (28\% at the $16 \mu \mathrm{M}$ Se dose), Ca (32\% at the $16 \mu \mathrm{M}$ Se dose), and $\mathrm{Mg}(19 \%$ at the $16 \mu \mathrm{M}$ Se dose) compared to the control treatment (Table 2). In contrast, an opposite effect was found in tatsoi, whereby the content of phosphorus and magnesium decreased at doses of $8 \mu \mathrm{M}$ (23\% and 36\%, respectively) and $16 \mu \mathrm{M} \mathrm{Se}(14 \%$ and $23 \%$, respectively), while the $\mathrm{K}$ and Ca concentration significantly decreased only at the dose of $8 \mu \mathrm{M}$ Se by $30 \%$ and $36 \%$, respectively, compared to the control. Regarding Na accumulation, in coriander and green basil, an increase of $18 \%$ and $14 \%$ was observed, respectively, at a dose of $16 \mu \mathrm{M} \mathrm{Se}$, while on the contrary, in purple basil and tatsoi, an average reduction of 30\% and 36\% was noted, respectively, at both Se applications (Table 2).

Concerning the microelement contents, a significant increase of $7 \%$ and $17 \%$ of $\mathrm{Fe}, 8 \%$ and $15 \%$ of $\mathrm{Zn}$, and $22 \%$ and $31 \%$ of Mn was observed in purple basil at doses of 8 and $16 \mu \mathrm{M} \mathrm{Se}$, respectively, compared to the control. Likewise, a significant rise of $9 \%$ and $24 \%$ of Fe and $17 \%$ and $59 \%$ of $\mathrm{Zn}$ was found in coriander at doses of 8 and $16 \mu \mathrm{M}$ Se, respectively; whereas Mn increased by $41 \%$ merely at the dose of $16 \mu \mathrm{M}$ Se. Contrarily, in tatsoi, a decrease of $43 \%$ and $22 \%$ of $\mathrm{Fe}, 20 \%$ and $10 \%$ of $\mathrm{Zn}$, and $37 \%$ and $24 \%$ of Mn was noted at doses of 8 and $16 \mu \mathrm{M}$ Se, respectively, in comparison to the control. In green basil, the addition of selenium to the nutrient solution at both doses reduced the zinc content on average by $59 \%$ and increased the manganese concentration on average by $67 \%$, while Fe decreased by $4 \%$ only at the dose of $8 \mu \mathrm{M}$ Se.

To the best of our knowledge, there are currently no works in the literature regarding the effect of Se biofortification on microgreens' mineral contents. However, the influence of Se applications on the macro and micronutrient content is not understood at all but appears to differ in a genotype-specific way. In coriander and basil (both cultivars), all macroelements tended to increase with Se treatments while an opposite effect was found in tatsoi. Our results are consistent with the findings observed in various studies on mature plants treated with selenium, in which $\mathrm{K}, \mathrm{P}, \mathrm{Ca}$, and $\mathrm{Mg}$ increased or decreased depending on the species and/or cultivar $[43,66,67]$. Likewise, iron and manganese microelements increased in coriander and purple basil with Se applications as found by Rios et al. [67] on lettuce, while iron, zinc, and manganese significantly decreased in tatsoi according to the results found by Wu and Huang [66] on white clover.

\subsection{Selenium Biofortification and Consumer Safety}

In selenium biofortification programs, it is fundamental that the selected crops are able to assimilate and accumulate this element in the edible portions of the plant. In the current study, all microgreen genotypes incurred an increase in Se content in response to the increasing Se doses applied. Across Se treatments, green basil reached the highest selenium content $\left(72.83 \mu \mathrm{g} \mathrm{g}^{-1} \mathrm{dw}\right)$ on average followed by purple basil (54.14 $\left.\mu \mathrm{g} \mathrm{g}^{-1} \mathrm{dw}\right)$, tatsoi (27.54 $\left.\mu \mathrm{g} \mathrm{g}^{-1} \mathrm{dw}\right)$, and coriander (11.60 $\left.\mu \mathrm{g} \mathrm{g}^{-1} \mathrm{dw}\right)$ (Figure 2). In particular, selenium content gradually increased with the amount of supplied Se in all four microgreen genotypes: In coriander $0.05,8.57$, and $26.18 \mu \mathrm{g} \mathrm{g}^{-1} \mathrm{dw}$; in green basil 1.10, 67.35, and $150.03 \mu \mathrm{g} \mathrm{g}^{-1} \mathrm{dw}_{\text {; }}$ in purple basil 3.04, 50.10, and $109.28 \mu \mathrm{g} \mathrm{g}^{-1} \mathrm{dw}$; whereas in tatsoi, $0.04,21.24$, and $61.34 \mu \mathrm{g} \mathrm{g}{ }^{-1} \mathrm{dw}_{\text {at }}$ doses of 0,8 , and $16 \mu \mathrm{M}$, respectively (Figure 2). Our findings were in agreement with previous works on microgreens of buckwheat [46], basil [9], and wheat [10], demonstrating the efficacy of achieving Se biofortification of microgreens. Furthermore, our findings corroborate previous findings on plant roots' capability for selenium uptake through passive diffusion and sulfate transporters due to the chemical similarity of this element with sulfur, and then it is transferred to the shoots via xylem $[16,27,28]$. It is well established that selenate assimilation in plants occurs through an active transport process led by sulfate transporters (SULTRs) [27]. SULTRs mediate the sulfate movement in the vascular bundles, 
therefore both sulphate and selenate are actively accumulated against their electrochemical gradient in the plant cells $[27,57]$.

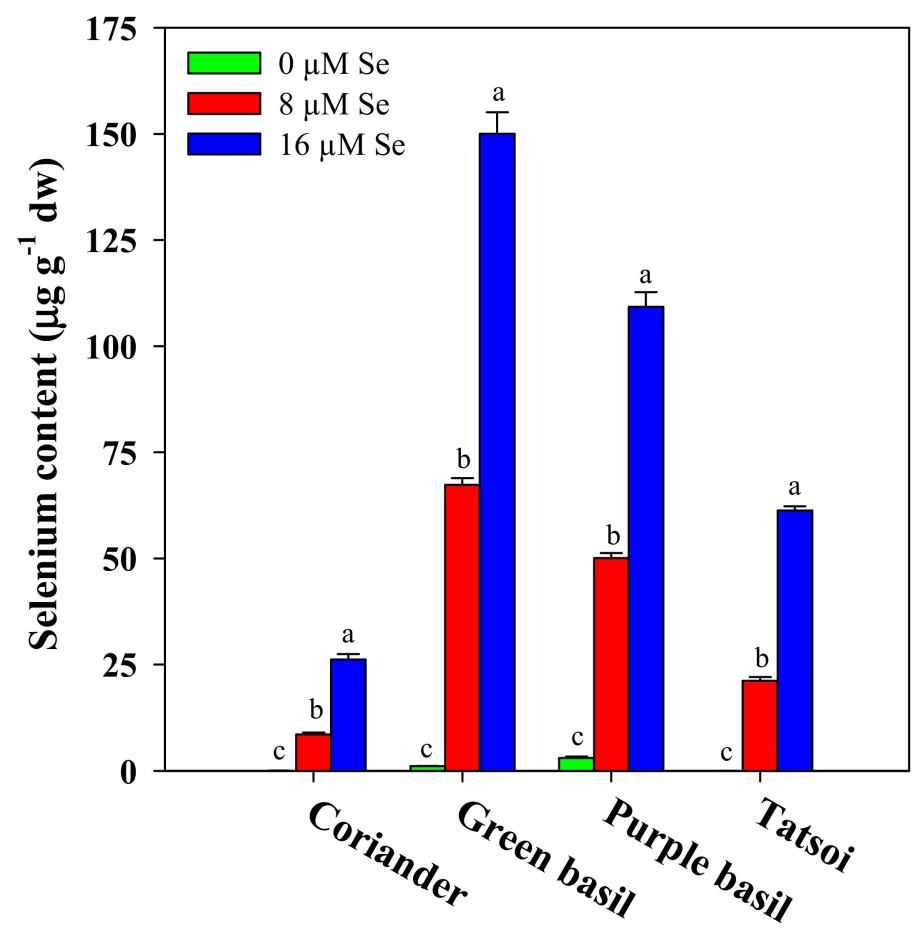

Figure 2. Effects of the selenium concentration on selenium biofortification of four microgreen genotypes grown in a growth chamber on a capillary mat substrate under three Se concentrations applied in the nutrient solution. The different letters $(\mathrm{a}-\mathrm{c})$ above bars indicate significant mean differences within each genotype according to Duncan's multiple range tests $(p \leq 0.05)$. The values are the means of three replicates. Vertical bars indicate $\pm \mathrm{SE}$ of means.

Selenium has been recognized as a trace mineral essential for human health as its deficiency causes serious diseases, such as cardiovascular diseases, cancer, viral infections, and diabetes [14-16]. However, it is characterized by a narrow range between the deficiency level $\left(55 \mu \mathrm{g} \mathrm{day}^{-1}\right)$ and the toxicity level $\left(400 \mu \mathrm{g} \mathrm{day}^{-1}\right)$ [17,19]. The Mediterranean diet is based on cereals, vegetables, fruit, meat, and dairy products and these foods are normally sufficient to guarantee, on average, a total Se intake of about $80 \mu \mathrm{g} \mathrm{day}^{-1}$ per person [68]. However, the dietary habits of the Mediterranean populations are changing, thereby introducing the risk of deficiencies in particular vitamins and minerals. On the other hand, in some countries, such as Brazil, a per capita daily intake of only $25 \mu \mathrm{g}$ Se was found among the population, requiring an integration of at least $30 \mu \mathrm{g}$ Se day ${ }^{-1}$ [69]. The literature provides no data regarding the average amount of daily consumed microgreens; however, considering that microgreens are normally adopted in minute quantities in order to garnish and enhance the taste of salad mix, meat, or fish [7], the average daily serving could be assumed to be around $10 \mathrm{~g} f w$. In the current study, Se daily intake increased linearly in all microgreen genotypes with the Se dose, ranging from 0.07 to $33.6 \mu \mathrm{g} \mathrm{day}^{-1}$ in coriander, 1.12 to $178 \mu \mathrm{g} \mathrm{day}^{-1}$ in green basil, 2.60 to $98.4 \mu \mathrm{g}$ day $^{-1}$ in purple basil, and from 0.04 to $49.5 \mu \mathrm{g} \mathrm{day}^{-1}$ in tatsoi (Table 3). Therefore, the percentage of RDA-Se increased with the same trend, reaching a peak at the $16 \mu \mathrm{M}$ Se dose. Then, in countries like Brazil, the RDA can be satisfied by consuming, for example, $10 \mathrm{~g} \mathrm{fw} \mathrm{day}{ }^{-1}$ of coriander at the $16 \mu \mathrm{M}$ Se dose, $4 \mathrm{~g} \mathrm{fw}_{\text {day }^{-1}}$ of green basil at the $8 \mu \mathrm{M}$ Se dose, $7 \mathrm{~g} \mathrm{fw}$ day $^{-1}$ of purple basil at the $8 \mu \mathrm{M}$ Se dose, or $6 \mathrm{~g} \mathrm{fw}$ day $^{-1}$ of tatsoi at the $16 \mu \mathrm{M}$ Se dose (Table 3). In addition, in order to examine the risks to human health, the green vegetables' hazard quotient (HQgv) was calculated according to the USEPA protocol [48]. In our experiment, HQgv increased with the Se application rate, ranging overall from 
0.00 to 0.45 ; therefore, the 10 -g daily portion of biofortified microgreens can be considered safe since the values of HQgv were less than 1 in all four microgreen genotypes and for all Se doses (Table 3).

Table 3. Se daily intake, percentage of recommended daily allowance for Se (RDA-Se), and hazard quotient (HQgv) for Se intake by adult humans (70-kg body weight), through the consumption of 10-g portions of fresh microgreens grown on a capillary mat substrate in a growth chamber under three Se concentrations applied in the nutrient solution.

\begin{tabular}{|c|c|c|c|c|}
\hline Genotype & Selenium & $\begin{array}{l}\text { Se Intake with } 10 \mathrm{~g} f \mathrm{w} \\
\text { of Microgreens } \\
\left(\mu \mathrm{g} \mathrm{day}^{-1}\right)\end{array}$ & $\begin{array}{c}\text { RDA-Se with } 10 \mathrm{~g} \\
\mathrm{fw} \text { of Microgreens } \\
(\%)\end{array}$ & $\begin{array}{c}\mathrm{HQ}_{\mathrm{gv}} \text { with } 10 \mathrm{~g} \mathrm{fw} \\
\text { of Microgreens }\end{array}$ \\
\hline \multirow{3}{*}{ Coriander } & $0 \mu \mathrm{M}$ & $0.07 \pm 0.0 \mathrm{c}$ & $0.12 \pm 0.0 \mathrm{c}$ & $0.00 \pm 0.00 c$ \\
\hline & $8 \mu \mathrm{M}$ & $11.5 \pm 0.8 \mathrm{~b}$ & $20.8 \pm 1.5 b$ & $0.03 \pm 0.00 b$ \\
\hline & $16 \mu \mathrm{M}$ & $33.6 \pm 1.6 \mathrm{a}$ & $61.0 \pm 2.9 \mathrm{a}$ & $0.08 \pm 0.00 \mathrm{a}$ \\
\hline \multirow{5}{*}{ Green basil } & Significance & $* * *$ & $* * *$ & $* * *$ \\
\hline & $0 \mu \mathrm{M}$ & $1.12 \pm 0.1 \mathrm{c}$ & $2.03 \pm 0.1 \mathrm{c}$ & $0.00 \pm 0.00 c$ \\
\hline & $8 \mu \mathrm{M}$ & $73.2 \pm 1.7 \mathrm{~b}$ & $133 \pm 3.1 b$ & $0.18 \pm 0.00 b$ \\
\hline & $16 \mu \mathrm{M}$ & $178 \pm 5.5 \mathrm{a}$ & $325 \pm 10 a$ & $0.45 \pm 0.01 \mathrm{a}$ \\
\hline & Significance & $* * *$ & $* * *$ & $* * *$ \\
\hline \multirow{3}{*}{ Purple basil } & $0 \mu \mathrm{M}$ & $2.60 \pm 0.3 c$ & $4.73 \pm 0.6 \mathrm{c}$ & $0.01 \pm 0.00 c$ \\
\hline & $8 \mu \mathrm{M}$ & $46.0 \pm 2.0 \mathrm{~b}$ & $83.7 \pm 3.7 \mathrm{~b}$ & $0.12 \pm 0.01 b$ \\
\hline & $16 \mu \mathrm{M}$ & $98.4 \pm 1.5 \mathrm{a}$ & $179 \pm 2.6 \mathrm{a}$ & $0.25 \pm 0.00 \mathrm{a}$ \\
\hline \multirow{5}{*}{ Tatsoi } & Significance & $* * *$ & $* * *$ & $* * *$ \\
\hline & $0 \mu \mathrm{M}$ & $0.04 \pm 0.0 \mathrm{c}$ & $0.07 \pm 0.0 \mathrm{c}$ & $0.00 \pm 0.00 c$ \\
\hline & $8 \mu \mathrm{M}$ & $17.0 \pm 1.2 \mathrm{~b}$ & $31.0 \pm 2.2 \mathrm{~b}$ & $0.04 \pm 0.00 \mathrm{~b}$ \\
\hline & $16 \mu \mathrm{M}$ & $49.5 \pm 1.0 \mathrm{a}$ & $90.0 \pm 1.9 \mathrm{a}$ & $0.12 \pm 0.00 \mathrm{a}$ \\
\hline & Significance & $* * *$ & $* * *$ & $* * *$ \\
\hline
\end{tabular}

*** Significant at $p \leq 0.001$. Different letters within each column indicate significant mean differences within each genotype according to Duncan's multiple range tests $(p \leq 0.05)$. All data are expressed as mean $\pm \mathrm{SE}, n=3$.

\subsection{Target Carotenoids}

Carotenoids are essential hydrophobic molecules that have a lipophilic antioxidant capacity mainly due to the conjugated double bonds of their long polyene chain, which are capable of inhibiting reactive oxygen species (ROS) and reducing oxidative damage [70]. In particular, lutein and $\beta$-carotene are the most widely distributed carotenoids in fruits and vegetables frequently consumed by the population [71]. Lutein plays an antioxidant role in macular surface membranes, as it is able to absorb any blue light striking the retina, which is thought to cause degeneration of the delicate surface membrane [72], while $\beta$-carotene, being a retinol precursor with a high conversion rate, supplies the human diet a substantial amount of vitamin A that is essential for immune function and vision [73].

The carotenoid concentration of the microgreens was quite variable among the four genotypes; in particular, the lutein content was on average higher in purple basil $\left(142.8 \mathrm{mg} \mathrm{kg}^{-1} \mathrm{dw}\right)$ and lower in green basil ( $95.0 \mathrm{mg} \mathrm{kg}^{-1} \mathrm{dw}$ ), whereas $\beta$-carotene values were the highest in coriander $(311.6 \mathrm{mg}$ $\left.\mathrm{kg}^{-1} \mathrm{dw}\right)$ and the lowest in green basil $\left(217.7 \mathrm{mg} \mathrm{kg}^{-1} \mathrm{dw}\right)$ and tatsoi $\left(215.3 \mathrm{mg} \mathrm{kg}^{-1} \mathrm{dw}\right)$. In basil, Se treatment at the dose of $8 \mu \mathrm{M}$ increased the lutein content by $7 \%$ and $19 \%$, respectively, in the green and purple cultivars (Figure 3B). Likewise, in tatsoi, the lutein concentration was significantly higher at the dose of $8 \mu \mathrm{M}$ Se $(123 \%)$ and $16 \mu \mathrm{M}$ Se (139\%) with respect to the control, whereas in coriander, the Se treatments elicited a reduction of the same molecule by $20 \%$ and $28 \%$ at doses of 8 and $16 \mu \mathrm{M}$, respectively (Figure 3B). Regarding the $\beta$-carotene concentration, Se treatments reduced the content of this compound in green basil by $4 \%$ and $19 \%$ and in purple basil by $14 \%$ and $11 \%$ at doses of 8 and 16 $\mu \mathrm{M}$, respectively (Figure 3A). On the contrary, in tatsoi, the $\beta$-carotene content was significantly higher with Se applications at doses of $8(59 \%)$ and $16 \mu \mathrm{M}(70 \%)$, while in coriander, there was an increase of $4 \%$ at the dose of $8 \mu \mathrm{M}$ Se (Figure $3 \mathrm{~A}$ ). 


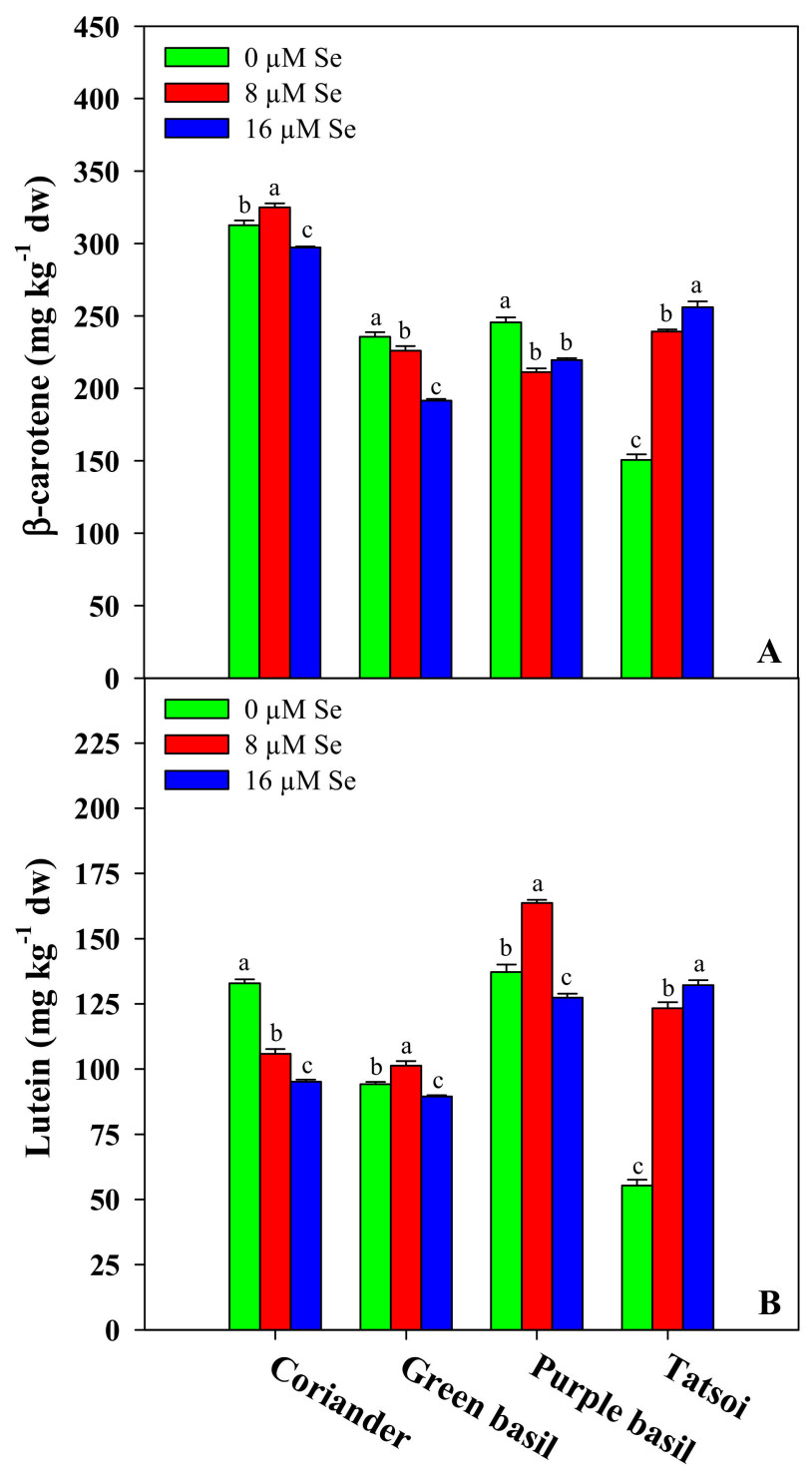

Figure 3. Effects of the selenium concentration on the $\beta$-carotene (A) and lutein (B) contents of four microgreen genotypes grown in a growth chamber on a capillary mat substrate under three Se concentrations applied in the nutrient solution. The different letters $(\mathrm{a}-\mathrm{c})$ above the bars indicate significant mean differences within each genotype according to Duncan's multiple range tests $(p \leq 0.05)$. The values are the means of three replicates. Vertical bars indicate \pm SE of means.

To our knowledge, there is one work [40] on pea sprouts regarding the effect of Se biofortification on $\beta$-carotene and lutein contents, but there are no reports in the literature on this topic concerning microgreens. However, a significant increase in the total carotenoid content was found in Se-biofortified wheat microgreens grown in a deep flow technique hydroponic system [10]. This finding is in agreement with our results on tatsoi (both carotenoids) at both Se doses, and on coriander ( $\beta$-carotene) and both basil cultivars (lutein) at the dose of $8 \mu \mathrm{M}$ Se (Figure 3A,B). Indeed, Se applications enhance the biosynthesis of photosynthetic pigments in plants, triggering the repair of chloroplasts damaged by abiotic stress and ROS $[55,74,75]$. However, an opposite effect was found in rice sprouts by D'Amato et al. [49], in which both selenite and selenate applications entailed a reduction in the total carotenoid content. This latter result was consistent with the decrease of $\beta$-carotene in basil and lutein in coriander that occurred in our experiment (Figure 3A,B). On the other hand, in previous work on Arabidopsis, it was demonstrated that the Se supply may downregulate phytoene synthase, which is the key enzyme involved in carotenoid biosynthesis [76]. Therefore, these findings denote that the 
activation of molecular and physiological mechanisms influences differently the biosynthesis and accumulation of secondary metabolites according to a genotype-dependent response [31].

\subsection{Phenolic Compounds Profiling}

The Q Exactive Orbitrap LC-MS/MS analysis revealed the presence of 27 polyphenols among the four microgreen genotypes treated with Se. The chromatographic separation and quantification highlighted a substantial difference in the phenolic composition between the different microgreen genotypes. Irrespective of Se treatments, green basil had the highest level of total polyphenol detected on average $\left(13,698 \mu \mathrm{g} \mathrm{g}^{-1} \mathrm{dw}\right)$ closely followed by purple basil $\left(10,830 \mu \mathrm{g} \mathrm{g}{ }^{-1} \mathrm{dw}\right)$ and coriander $\left(10,237 \mu \mathrm{g} \mathrm{g}^{-1} \mathrm{dw}\right)$, while tatsoi $\left(594 \mu \mathrm{g} \mathrm{g}^{-1} \mathrm{dw}\right)$ showed a much lower phenolic content (Table 4). Comparable ranges of the total polyphenols content were previously reported by Xiao et al. [8] (1500-7000 $\left.\mu \mathrm{g} \mathrm{g}^{-1} \mathrm{dw}\right)$ and by Kyriacou et al. [2] (700-6000 $\left.\mu \mathrm{g} \mathrm{g}^{-1} \mathrm{dw}\right)$ for peat-grown microgreens; however, the range maxima presently reported exceed those of the aforementioned works, likely owing to the slower growth rate and higher dry matter content of microgreens grown on a capillary mat. Regarding the effect of the Se treatments, in coriander and tatsoi microgreens, the application of $16 \mu \mathrm{M}$ Se increased the total polyphenols content by $21 \%$ and $95 \%$, respectively, compared to the untreated control. However, in green basil, the sum of detected phenolic acids was $32 \%$ higher only at the $8 \mu \mathrm{M}$ Se application with respect to the control, while in the purple cultivar, the total polyphenols content was significantly decreased by $22 \%$ at both Se treatments.

In addition to the total quantity of polyphenols detected, the four microgreen genotypes differed specifically in the levels of key phenolic compounds. Irrespective of Se treatments, in coriander, chlorogenic acid $\left(4516 \mu \mathrm{g} \mathrm{g}^{-1} \mathrm{dw}\right)$ and rutin $\left(3999 \mu \mathrm{g} \mathrm{g}^{-1} \mathrm{dw}\right)$ were on average the most abundant; in tatsoi, the prevalent polyphenols were caffeic acid hexoside $\left(258 \mu \mathrm{g} \mathrm{g}^{-1} \mathrm{dw}\right)$ and kaempferol-3-O (caffeoyl) sophoroside-7-O-glucoside $\left(126 \mu \mathrm{g} \mathrm{g}^{-1} \mathrm{dw}\right)$; while in both green and purple basil, the most abundant on average were cichoric acid (1390 and $609 \mu \mathrm{g} \mathrm{g}^{-1} \mathrm{dw}$, respectively) and rosmarinic acid (11747 and $9950 \mu \mathrm{g} \mathrm{g}^{-1} \mathrm{dw}$, respectively) (Table 4). In coriander, a similar phenolic profile was reported in mature plants [77], with chlorogenic acid and rutin present among the major compounds. A previous work by Kyriacou et al. [2] confirmed the presence of kaempferol-3-O (caffeoyl) sophoroside-7-O-glucoside among the main phenolic compounds of tatsoi microgreens, while the caffeic acid hexoside was not detected. In the case of basil, cichoric acid and rosmarinic acid were also among the most abundant phenols present in the mature tissues of this species [78], suggesting that the phenolic transformation of basil did not incur significant changes with ontogenesis.

Significant differences in the polyphenolic profile were also observed in response to Se treatments. In coriander, the concentration of rutin, feruloyl quinic acid, luteolin-3-O-rutinoside, and kaempferol-3-O-rutinoside was higher than the untreated control at both Se doses, while quercitin-3-O-glucoside and dicaffeoylquinic acid increased at the lowest Se dose and ferulic acid increased only at the highest Se dose (Table 4). A similar treatment effect was found in tatsoi, in which kaempferol-3-O-sophoroside-7-O-glucoside, quercetin-sophoroside, apigenin-7-O-rutinoside, kaempferol-7-O-glucoside, and apigenin-7-rhamnoside-4-rutinoside were higher at both Se doses, while chlorogenic acid and feruloyl quinic acid increased at the $8 \mu \mathrm{M}$ Se dose and caffeic acid hexoside, kaempferol-3-O(caffeoyl)sophoroside-7-O-glucoside, $\mathrm{O}$ (feruoyll)sophoroside-7-O-glucoside isorhamnetin-3-gentiobioside, kaempferol-3-O(coumaroyl)soph-7-O-glucoside, luteolin-7-O-glucoside, kaempferol-3-O(feroyll)sophoroside-7-O-glucoside, and coumaroyl quinic acid increased significantly only at thee $16 \mu \mathrm{M}$ Se dose (Table 4 ). 
Table 4. Phenolic profiles and total phenolic composition of four microgreen genotypes grown in a growth chamber on a capillary mat substrate under three Se concentrations applied in the nutrient solution.

\begin{tabular}{|c|c|c|c|c|c|c|c|c|c|c|c|c|c|c|c|c|}
\hline \multirow[b]{2}{*}{ Polyphenol ( $\left.\mu \mathrm{g} \mathrm{g}^{-1} \mathrm{dw}\right)$} & \multicolumn{4}{|c|}{ Coriander } & \multicolumn{4}{|c|}{ Green basil } & \multicolumn{4}{|c|}{ Purple basil } & \multicolumn{4}{|c|}{ Tatsoi } \\
\hline & $\begin{array}{c}0 \mu \mathrm{M} \\
\mathrm{Se}\end{array}$ & $\begin{array}{c}8 \mu \mathrm{M} \\
\mathrm{Se}\end{array}$ & $\begin{array}{c}16 \mu M \\
S e\end{array}$ & Sig. & $\begin{array}{c}0 \mu \mathrm{M} \\
\mathrm{Se}\end{array}$ & $\begin{array}{c}8 \mu \mathrm{M} \\
\mathrm{Se}\end{array}$ & $\begin{array}{c}16 \mu M \\
S e\end{array}$ & Sig. & $\begin{array}{c}0 \mu \mathrm{M} \\
\mathrm{Se}\end{array}$ & $\begin{array}{c}8 \mu \mathrm{M} \\
\mathrm{Se}\end{array}$ & $\begin{array}{c}16 \mu M \\
\text { Se }\end{array}$ & Sig. & $\begin{array}{c}0 \mu \mathrm{M} \\
\mathrm{Se}\end{array}$ & $\begin{array}{c}8 \mu \mathrm{M} \\
\mathrm{Se}\end{array}$ & $\begin{array}{c}16 \mu \mathrm{M} \\
\mathrm{Se}\end{array}$ & Sig. \\
\hline cichoric acid & nd & nd & nd & na & $\begin{array}{l}841 \pm \\
63.8 \mathrm{~b}\end{array}$ & $\begin{array}{l}2408 \pm \\
26.6 \mathrm{a} \\
\end{array}$ & $\begin{array}{l}921 \pm \\
30.0 \mathrm{~b}\end{array}$ & $* * *$ & $\begin{array}{l}813 \pm \\
58.2 \mathrm{a}\end{array}$ & $\begin{array}{l}533 \pm \\
24.3 \mathrm{~b} \\
\end{array}$ & $\begin{array}{l}481 \pm \\
16.8 \mathrm{~b} \\
\end{array}$ & $* *$ & nd & nd & nd & na \\
\hline chlorogenic acid & $\begin{array}{c}4504 \pm \\
409\end{array}$ & $\begin{array}{c}4526 \pm \\
247\end{array}$ & $\begin{array}{c}4519 \pm \\
315 \\
\end{array}$ & ns & $\begin{array}{l}208 \pm \\
15.2 \mathrm{~b}\end{array}$ & $\begin{array}{l}272 \pm \\
14.8 \mathrm{a} \\
\end{array}$ & $\begin{array}{l}171 \pm \\
2.61 \mathrm{~b} \\
\end{array}$ & ** & $\begin{array}{l}7.12 \pm \\
0.18 \mathrm{a} \\
\end{array}$ & $\begin{array}{l}6.78 \pm \\
0.20 \mathrm{a} \\
\end{array}$ & $\begin{array}{l}2.83 \pm \\
0.29 \mathrm{~b}\end{array}$ & $* * *$ & $\begin{array}{l}12.8 \pm \\
1.36 \mathrm{~b} \\
\end{array}$ & $\begin{array}{l}19.4 \pm \\
1.20 \mathrm{a} \\
\end{array}$ & $\begin{array}{l}12.4 \pm \\
1.43 \mathrm{~b} \\
\end{array}$ & * \\
\hline caffeic acid & $\begin{array}{l}0.67 \pm \\
0.04 \mathrm{~b}\end{array}$ & $\begin{array}{l}0.99 \pm \\
0.05 \mathrm{a} \\
\end{array}$ & $\begin{array}{l}0.86 \pm \\
0.04 \mathrm{a}\end{array}$ & ** & $\begin{array}{l}11.2 \pm \\
0.80 \mathrm{~b}\end{array}$ & $\begin{array}{l}17.1 \pm \\
1.01 \mathrm{a} \\
\end{array}$ & $\begin{array}{l}8.88 \pm \\
0.24 \mathrm{~b}\end{array}$ & $* * *$ & $\begin{array}{c}10.89 \pm \\
0.86 \mathrm{a} \\
\end{array}$ & $\begin{array}{l}6.33 \pm \\
0.43 \mathrm{~b} \\
\end{array}$ & $\begin{array}{l}5.82 \pm \\
0.16 \mathrm{~b} \\
\end{array}$ & $* * *$ & $\begin{array}{l}0.70 \pm \\
0.06 \mathrm{c}\end{array}$ & $\begin{array}{l}0.87 \pm \\
0.02 \mathrm{~b}\end{array}$ & $\begin{array}{l}1.35 \pm \\
0.05 \mathrm{a}\end{array}$ & $* * *$ \\
\hline kaempferol-3-O-sophoroside-7-O-glucoside & nd & nd & nd & na & nd & nd & nd & na & nd & nd & nd & na & $\begin{array}{l}0.66 \pm \\
0.01 \mathrm{c} \\
\end{array}$ & $\begin{array}{l}2.47 \pm \\
0.17 \mathrm{~b}\end{array}$ & $\begin{array}{c}7.67 \pm \\
0.46 \mathrm{a}\end{array}$ & $* * *$ \\
\hline quercetin-sophoroside & $\begin{array}{l}1.46 \pm \\
0.02 \mathrm{a}\end{array}$ & $\begin{array}{l}1.23 \pm \\
0.04 \mathrm{~b}\end{array}$ & $\begin{array}{l}0.85 \pm \\
0.02 \mathrm{c} \\
\end{array}$ & $* * *$ & $\begin{array}{l}0.65 \pm \\
0.03 \mathrm{~b}\end{array}$ & $\begin{array}{l}1.49 \pm \\
0.02 \mathrm{a} \\
\end{array}$ & $\begin{array}{l}0.42 \pm \\
0.03 \mathrm{c}\end{array}$ & $* * *$ & $\begin{array}{l}0.15 \pm \\
0.00 \mathrm{a} \\
\end{array}$ & $\begin{array}{l}0.11 \pm \\
0.01 \mathrm{~b}\end{array}$ & $\begin{array}{l}0.08 \pm \\
0.00 \mathrm{c}\end{array}$ & $* * *$ & $\begin{array}{l}12.4 \pm \\
0.65 \mathrm{~b} \\
\end{array}$ & $\begin{array}{l}26.0 \pm \\
3.20 \mathrm{a} \\
\end{array}$ & $\begin{array}{l}23.9 \pm \\
1.47 \mathrm{a} \\
\end{array}$ & $* *$ \\
\hline caffeic acid hexoside isomers & $\begin{array}{c}39.9 \pm \\
0.68 \mathrm{a}\end{array}$ & $\begin{array}{l}12.0 \pm \\
0.19 \mathrm{c} \\
\end{array}$ & $\begin{array}{l}17.7 \pm \\
1.09 \mathrm{~b}\end{array}$ & $* * *$ & $\begin{array}{l}6.26 \pm \\
0.71 \mathrm{c} \\
\end{array}$ & $\begin{array}{l}17.6 \pm \\
0.73 \mathrm{a} \\
\end{array}$ & $\begin{array}{l}9.45 \pm \\
0.73 \mathrm{~b}\end{array}$ & $* * *$ & $\begin{array}{l}13.0 \pm \\
0.62 \mathrm{a}\end{array}$ & $\begin{array}{l}7.34 \pm \\
0.71 \mathrm{~b}\end{array}$ & $\begin{array}{l}12.0 \pm \\
0.67 \mathrm{a} \\
\end{array}$ & ** & $\begin{array}{l}212 \pm \\
8.92 \mathrm{~b} \\
\end{array}$ & $\begin{array}{l}194 \pm \\
20.1 \mathrm{~b} \\
\end{array}$ & $\begin{array}{l}367 \pm \\
5.93 \mathrm{a} \\
\end{array}$ & $* * *$ \\
\hline 2-xylosylvitexin & nd & nd & nd & na & nd & nd & nd & na & $\begin{array}{c}5.04 \pm \\
0.56\end{array}$ & $\begin{array}{c}4.12 \pm \\
0.27 \\
\end{array}$ & $\begin{array}{c}4.04 \pm \\
0.14 \\
\end{array}$ & $\mathrm{~ns}$ & $\begin{array}{l}0.94 \pm \\
0.08 \mathrm{~b}\end{array}$ & $\begin{array}{l}0.85 \pm \\
0.04 \mathrm{~b}\end{array}$ & $\begin{array}{l}1.23 \pm \\
0.06 \mathrm{a}\end{array}$ & * \\
\hline kaempferol-3-O(caffeoyl)sophoroside-7-O-glucoside & nd & nd & nd & na & $\begin{array}{l}0.09 \pm \\
0.00 \mathrm{~b}\end{array}$ & $\begin{array}{l}0.15 \pm \\
0.00 \mathrm{a} \\
\end{array}$ & $\begin{array}{l}0.07 \pm \\
0.01 \mathrm{c} \\
\end{array}$ & ${ }^{* * *}$ & nd & nd & nd & na & $\begin{array}{l}94.6 \pm \\
6.25 \mathrm{~b} \\
\end{array}$ & $\begin{array}{l}93.2 \pm \\
7.66 \mathrm{~b} \\
\end{array}$ & $\begin{array}{l}190 \pm \\
1.88 \mathrm{a} \\
\end{array}$ & $* * *$ \\
\hline isorhamnetin-3-gentiobioside & nd & nd & nd & na & nd & nd & nd & na & nd & nd & nd & na & $\begin{array}{l}18.9 \pm \\
0.96 \mathrm{~b}\end{array}$ & $\begin{array}{l}18.7 \pm \\
0.50 \mathrm{~b}\end{array}$ & $\begin{array}{l}39.2 \pm \\
1.99 \mathrm{a}\end{array}$ & $* * *$ \\
\hline kaempferol-3-O-(coumaroyl)soph-7-O-glucoside & $\begin{array}{c}0.81 \pm \\
0.04\end{array}$ & $\begin{array}{c}0.11 \pm \\
0.01 \\
\end{array}$ & $\begin{array}{c}0.04 \pm \\
0.00\end{array}$ & $* * *$ & $\begin{array}{l}0.01 \pm \\
0.00 \mathrm{c}\end{array}$ & $\begin{array}{l}0.02 \pm \\
0.00 \mathrm{a} \\
\end{array}$ & $\begin{array}{l}0.02 \pm \\
0.00 \mathrm{~b}\end{array}$ & *** & $\begin{array}{l}18.8 \pm \\
0.62 \mathrm{a}\end{array}$ & $\begin{array}{l}8.48 \pm \\
0.25 \mathrm{~b} \\
\end{array}$ & $\begin{array}{l}7.42 \pm \\
0.63 \mathrm{~b} \\
\end{array}$ & $* * *$ & $\begin{array}{l}7.09 \pm \\
0.46 \mathrm{~b}\end{array}$ & $\begin{array}{l}7.62 \pm \\
0.38 \mathrm{~b}\end{array}$ & $\begin{array}{l}15.3 \pm \\
1.03 \mathrm{a}\end{array}$ & $* * *$ \\
\hline luteolin-7-O-glucoside & $\begin{array}{l}1.48 \pm \\
0.01 \mathrm{~b}\end{array}$ & $\begin{array}{l}1.47 \pm \\
0.01 \mathrm{~b} \\
\end{array}$ & $\begin{array}{l}1.60 \pm \\
0.05 \mathrm{a} \\
\end{array}$ & * & $\begin{array}{l}14.0 \pm \\
1.00 \mathrm{~b}\end{array}$ & $\begin{array}{l}31.3 \pm \\
1.19 \mathrm{a} \\
\end{array}$ & $\begin{array}{l}30.2 \pm \\
1.09 \mathrm{a} \\
\end{array}$ & *** & $\begin{array}{l}39.6 \pm \\
0.39 \mathrm{a} \\
\end{array}$ & $\begin{array}{l}24.4 \pm \\
0.67 \mathrm{~b} \\
\end{array}$ & $\begin{array}{l}22.7 \pm \\
0.94 \mathrm{~b} \\
\end{array}$ & $* * *$ & $\begin{array}{l}2.18 \pm \\
0.26 \mathrm{~b} \\
\end{array}$ & $\begin{array}{l}2.69 \pm \\
0.14 \mathrm{~b} \\
\end{array}$ & $\begin{array}{l}4.92 \pm \\
0.07 \mathrm{a} \\
\end{array}$ & $* * *$ \\
\hline apigenin-malonil-glucoside & $\begin{array}{l}0.04 \pm \\
0.00 \mathrm{~b}\end{array}$ & $\begin{array}{l}0.05 \pm \\
0.00 \mathrm{~b}\end{array}$ & $\begin{array}{l}0.07 \pm \\
0.00 \mathrm{a}\end{array}$ & $* * *$ & $\begin{array}{l}0.34 \pm \\
0.01 \mathrm{c} \\
\end{array}$ & $\begin{array}{l}0.76 \pm \\
0.03 \mathrm{a} \\
\end{array}$ & $\begin{array}{l}0.47 \pm \\
0.02 \mathrm{~b}\end{array}$ & $* * *$ & $\begin{array}{c}1.10 \pm \\
0.04\end{array}$ & $\begin{array}{c}0.99 \pm \\
0.02 \\
\end{array}$ & $\begin{array}{c}1.04 \pm \\
0.03 \\
\end{array}$ & ns & $\begin{array}{l}0.05 \pm \\
0.00 \mathrm{a} \\
\end{array}$ & $\begin{array}{l}0.02 \pm \\
0.00 \mathrm{c} \\
\end{array}$ & $\begin{array}{l}0.04 \pm \\
0.00 \mathrm{~b}\end{array}$ & $* * *$ \\
\hline kaempferol-3-O(feruoyll)sophoroside-7-O-glucoside & $\begin{array}{l}4.65 \pm \\
0.29 \mathrm{a} \\
\end{array}$ & $\begin{array}{l}0.31 \pm \\
0.01 \mathrm{~b}\end{array}$ & $\begin{array}{l}0.06 \pm \\
0.00 \mathrm{~b}\end{array}$ & $* * *$ & $\begin{array}{l}0.03 \pm \\
0.00 \mathrm{a} \\
\end{array}$ & $\begin{array}{l}0.02 \pm \\
0.00 \mathrm{~b}\end{array}$ & $\begin{array}{l}0.03 \pm \\
0.00 \mathrm{a}\end{array}$ & $* * *$ & $\begin{array}{l}0.59 \pm \\
0.04 \mathrm{a}\end{array}$ & $\begin{array}{l}0.26 \pm \\
0.02 \mathrm{~b}\end{array}$ & $\begin{array}{l}0.27 \pm \\
0.01 \mathrm{~b}\end{array}$ & $* * *$ & $\begin{array}{l}42.1 \pm \\
2.54 \mathrm{~b} \\
\end{array}$ & $\begin{array}{l}58.6 \pm \\
3.29 \mathrm{~b}\end{array}$ & $\begin{array}{l}108 \pm \\
7.91 \mathrm{a} \\
\end{array}$ & $* * *$ \\
\hline coumaroyl quinic acid & $\begin{array}{l}3.21 \pm \\
0.06 \mathrm{a}\end{array}$ & $\begin{array}{l}0.60 \pm \\
0.06 \mathrm{~b}\end{array}$ & $\begin{array}{l}0.10 \pm \\
0.01 \mathrm{c}\end{array}$ & $* * *$ & $\begin{array}{l}0.02 \pm \\
0.00 \mathrm{c}\end{array}$ & $\begin{array}{l}0.10 \pm \\
0.01 \mathrm{~b}\end{array}$ & $\begin{array}{l}0.14 \pm \\
0.00 \mathrm{a}\end{array}$ & $* * *$ & $\begin{array}{l}0.05 \pm \\
0.00 \mathrm{a}\end{array}$ & $\begin{array}{l}0.03 \pm \\
0.00 \mathrm{~b}\end{array}$ & $\begin{array}{l}0.01 \pm \\
0.00 \mathrm{c}\end{array}$ & $* * *$ & $\begin{array}{l}12.3 \pm \\
0.23 \mathrm{~b} \\
\end{array}$ & $\begin{array}{l}15.6 \pm \\
1.21 \mathrm{~b} \\
\end{array}$ & $\begin{array}{l}38.7 \pm \\
1.68 \mathrm{a} \\
\end{array}$ & $* * *$ \\
\hline rutin & $\begin{array}{c}3487 \pm \\
48.9 \mathrm{c}\end{array}$ & $\begin{array}{c}3857 \pm \\
35.7 \mathrm{~b}\end{array}$ & $\begin{array}{c}4653 \pm \\
86.8 \mathrm{a}\end{array}$ & $* * *$ & $\begin{array}{l}31.2 \pm \\
0.19 \mathrm{a}\end{array}$ & $\begin{array}{l}13.3 \pm \\
0.57 \mathrm{~b}\end{array}$ & $\begin{array}{l}14.1 \pm \\
0.63 \mathrm{~b}\end{array}$ & $* * *$ & $\begin{array}{c}3.42 \pm \\
0.06\end{array}$ & $\begin{array}{c}3.11 \pm \\
0.20\end{array}$ & $\begin{array}{c}3.23 \pm \\
0.05\end{array}$ & ns & $\begin{array}{l}3.16 \pm \\
0.29 \mathrm{~b}\end{array}$ & $\begin{array}{l}1.96 \pm \\
0.05 \mathrm{~b}\end{array}$ & $\begin{array}{l}2.37 \pm \\
0.02 \mathrm{a}\end{array}$ & $* *$ \\
\hline
\end{tabular}


Table 4. Cont.

\begin{tabular}{|c|c|c|c|c|c|c|c|c|c|c|c|c|c|c|c|c|}
\hline \multirow{2}{*}{ Polyphenol ( $\mu \mathrm{g} \mathrm{g}^{-1} \mathrm{dw}$ ) } & \multicolumn{4}{|c|}{ Coriander } & \multicolumn{4}{|c|}{ Green basil } & \multicolumn{4}{|c|}{ Purple basil } & \multicolumn{4}{|c|}{ Tatsoi } \\
\hline & $\begin{array}{c}0 \mu \mathrm{M} \\
\mathrm{Se}\end{array}$ & $\begin{array}{c}8 \mu \mathrm{M} \\
\mathrm{Se}\end{array}$ & $\begin{array}{c}16 \mu \mathrm{M} \\
\mathrm{Se}\end{array}$ & Sig. & $\begin{array}{c}0 \mu \mathrm{M} \\
\mathrm{Se}\end{array}$ & $\begin{array}{c}8 \mu \mathrm{M} \\
\mathrm{Se}\end{array}$ & $\begin{array}{c}16 \mu \mathrm{M} \\
\mathrm{Se}\end{array}$ & Sig. & $\begin{array}{c}0 \mu \mathrm{M} \\
\mathrm{Se}\end{array}$ & $\begin{array}{c}8 \mu \mathrm{M} \\
\mathrm{Se}\end{array}$ & $\begin{array}{c}16 \mu \mathrm{M} \\
\mathrm{Se}\end{array}$ & Sig. & $\begin{array}{c}0 \mu \mathrm{M} \\
\mathrm{Se}\end{array}$ & $\begin{array}{c}8 \mu \mathrm{M} \\
\mathrm{Se}\end{array}$ & $\begin{array}{c}16 \mu \mathrm{M} \\
\mathrm{Se}\end{array}$ & Sig. \\
\hline apigenin-7-O-rutinoside & $\begin{array}{l}0.30 \pm \\
0.02 \mathrm{a}\end{array}$ & $\begin{array}{l}0.12 \pm \\
0.05 \mathrm{~b}\end{array}$ & $\begin{array}{l}0.01 \pm \\
0.00 \mathrm{c}\end{array}$ & $* * *$ & nd & nd & nd & na & nd & nd & nd & na & $\begin{array}{l}4.55 \pm \\
0.19 \mathrm{c} \\
\end{array}$ & $\begin{array}{l}6.93 \pm \\
0.31 \mathrm{~b} \\
\end{array}$ & $\begin{array}{l}12.8 \pm \\
0.35 \mathrm{a} \\
\end{array}$ & $* * *$ \\
\hline quercetin-3-O-glucoside & $\begin{array}{l}88.9 \pm \\
5.38 \mathrm{~b} \\
\end{array}$ & $\begin{array}{l}118 \pm \\
2.32 \mathrm{a} \\
\end{array}$ & $\begin{array}{l}79.8 \pm \\
5.60 \mathrm{~b}\end{array}$ & $* *$ & $\begin{array}{l}4.08 \pm \\
0.03 \mathrm{~b}\end{array}$ & $\begin{array}{l}4.98 \pm \\
0.16 \mathrm{a} \\
\end{array}$ & $\begin{array}{l}1.61 \pm \\
0.03 \mathrm{c} \\
\end{array}$ & $* * *$ & $\begin{array}{l}39.2 \pm \\
1.02 \mathrm{a} \\
\end{array}$ & $\begin{array}{l}16.0 \pm \\
0.89 \mathrm{~b}\end{array}$ & $\begin{array}{l}6.83 \pm \\
0.60 \mathrm{c} \\
\end{array}$ & $* * *$ & $\begin{array}{l}0.54 \pm \\
0.00 \mathrm{c} \\
\end{array}$ & $\begin{array}{l}1.26 \pm \\
0.01 \mathrm{~b} \\
\end{array}$ & $\begin{array}{l}3.30 \pm \\
0.03 \mathrm{a} \\
\end{array}$ & $* * *$ \\
\hline feruloyl quinic acid & $\begin{array}{l}613 \pm \\
11.7 \mathrm{c}\end{array}$ & $\begin{array}{l}734 \pm \\
34.2 \mathrm{~b}\end{array}$ & $\begin{array}{c}1123 \pm \\
43.3 \mathrm{a}\end{array}$ & $* * *$ & $\begin{array}{l}2.78 \pm \\
0.04 \mathrm{c}\end{array}$ & $\begin{array}{l}39.6 \pm \\
0.80 \mathrm{a}\end{array}$ & $\begin{array}{l}9.67 \pm \\
0.17 \mathrm{~b}\end{array}$ & $* * *$ & $\begin{array}{l}13.4 \pm \\
1.02 \mathrm{a} \\
\end{array}$ & $\begin{array}{l}5.99 \pm \\
0.17 \mathrm{~b}\end{array}$ & $\begin{array}{l}5.55 \pm \\
0.15 \mathrm{~b}\end{array}$ & $* * *$ & $\begin{array}{l}4.65 \pm \\
0.20 \mathrm{~b}\end{array}$ & $\begin{array}{l}8.48 \pm \\
0.29 \mathrm{a} \\
\end{array}$ & $\begin{array}{l}4.99 \pm \\
0.40 \mathrm{~b}\end{array}$ & $* * *$ \\
\hline rosmarinic acid & nd & nd & nd & na & $\begin{array}{c}10969 \\
\pm 765 \mathrm{~b} \\
\end{array}$ & $\begin{array}{c}13025 \\
\pm 128 \mathrm{a} \\
\end{array}$ & $\begin{array}{l}11246 \\
\pm 71 \mathrm{~b} \\
\end{array}$ & * & $\begin{array}{c}11532 \\
\pm 428 \mathrm{a} \\
\end{array}$ & $\begin{array}{c}9236 \pm \\
246 \mathrm{~b}\end{array}$ & $\begin{array}{c}9081 \pm \\
176 \mathrm{~b}\end{array}$ & ** & nd & nd & nd & na \\
\hline cirsiliol & nd & nd & nd & na & $\begin{array}{l}44.9 \pm \\
1.44 \mathrm{c} \\
\end{array}$ & $\begin{array}{l}116 \pm \\
2.17 \text { a } \\
\end{array}$ & $\begin{array}{l}67.3 \pm \\
0.85 \mathrm{~b} \\
\end{array}$ & $* * *$ & $\begin{array}{l}31.9 \pm \\
1.53 \mathrm{a} \\
\end{array}$ & $\begin{array}{l}18.9 \pm \\
0.49 \mathrm{~b} \\
\end{array}$ & $\begin{array}{l}20.1 \pm \\
0.64 \mathrm{~b}\end{array}$ & $* * *$ & nd & nd & nd & na \\
\hline ferulic acid & $\begin{array}{l}32.7 \pm \\
0.97 \mathrm{~b}\end{array}$ & $\begin{array}{l}36.4 \pm \\
0.94 \mathrm{~b}\end{array}$ & $\begin{array}{l}55.8 \pm \\
2.19 \mathrm{a} \\
\end{array}$ & $* * *$ & $\begin{array}{l}25.5 \pm \\
0.54 \mathrm{~b}\end{array}$ & $\begin{array}{l}50.3 \pm \\
2.34 \mathrm{a}\end{array}$ & $\begin{array}{l}21.6 \pm \\
0.76 \mathrm{~b}\end{array}$ & $* * *$ & $\begin{array}{l}36.0 \pm \\
1.29 \mathrm{a} \\
\end{array}$ & $\begin{array}{l}24.9 \pm \\
0.66 \mathrm{~b}\end{array}$ & $\begin{array}{l}22.0 \pm \\
0.24 \mathrm{~b}\end{array}$ & $* * *$ & $\begin{array}{l}0.47 \pm \\
0.01 \mathrm{c} \\
\end{array}$ & $\begin{array}{l}0.84 \pm \\
0.06 \mathrm{~b}\end{array}$ & $\begin{array}{l}1.02 \pm \\
0.01 \mathrm{a}\end{array}$ & $* * *$ \\
\hline luteolin-3-O-rutinoside & $\begin{array}{l}248 \pm \\
5.90 \mathrm{c} \\
\end{array}$ & $\begin{array}{l}532 \pm \\
15.5 \mathrm{a} \\
\end{array}$ & $\begin{array}{l}374 \pm \\
14.6 \mathrm{~b} \\
\end{array}$ & $* * *$ & $\begin{array}{l}4.56 \pm \\
0.03 \mathrm{a} \\
\end{array}$ & $\begin{array}{l}3.99 \pm \\
0.13 \mathrm{~b}\end{array}$ & $\begin{array}{l}2.52 \pm \\
0.06 \mathrm{c} \\
\end{array}$ & $* * *$ & $\begin{array}{l}15.1 \pm \\
0.65 \mathrm{a} \\
\end{array}$ & $\begin{array}{l}10.4 \pm \\
0.32 \mathrm{~b}\end{array}$ & $\begin{array}{l}10.2 \pm \\
0.59 \mathrm{~b}\end{array}$ & $* * *$ & nd & nd & nd & na \\
\hline kaempferol-7-O-glucoside & $\begin{array}{l}3.06 \pm \\
0.13 \mathrm{a} \\
\end{array}$ & $\begin{array}{l}2.23 \pm \\
0.02 \mathrm{c} \\
\end{array}$ & $\begin{array}{l}2.65 \pm \\
0.05 \mathrm{~b} \\
\end{array}$ & $* * *$ & $\begin{array}{l}2.50 \pm \\
0.13 \mathrm{a} \\
\end{array}$ & $\begin{array}{l}1.79 \pm \\
0.03 \mathrm{~b} \\
\end{array}$ & $\begin{array}{l}1.74 \pm \\
0.09 \mathrm{~b} \\
\end{array}$ & $* *$ & $\begin{array}{l}13.4 \pm \\
1.15 \mathrm{a} \\
\end{array}$ & $\begin{array}{l}9.52 \pm \\
0.48 \mathrm{~b} \\
\end{array}$ & $\begin{array}{l}9.23 \pm \\
0.25 \mathrm{~b} \\
\end{array}$ & * & $\begin{array}{l}3.30 \pm \\
0.09 \mathrm{c} \\
\end{array}$ & $\begin{array}{l}4.02 \pm \\
0.28 \mathrm{~b} \\
\end{array}$ & $\begin{array}{l}8.38 \pm \\
0.15 \mathrm{a} \\
\end{array}$ & $* * *$ \\
\hline dicaffeoylquinic acid & $\begin{array}{l}10.7 \pm \\
1.28 \mathrm{~b}\end{array}$ & $\begin{array}{l}15.6 \pm \\
0.42 \mathrm{a}\end{array}$ & $\begin{array}{l}9.60 \pm \\
0.35 \mathrm{~b}\end{array}$ & ** & $\begin{array}{l}1.16 \pm \\
0.04 \mathrm{~b}\end{array}$ & $\begin{array}{l}3.09 \pm \\
0.10 \mathrm{a} \\
\end{array}$ & $\begin{array}{l}2.83 \pm \\
0.13 \mathrm{a} \\
\end{array}$ & $* * *$ & $\begin{array}{l}0.95 \pm \\
0.03 \mathrm{a}\end{array}$ & $\begin{array}{l}0.67 \pm \\
0.04 \mathrm{~b}\end{array}$ & $\begin{array}{l}0.42 \pm \\
0.04 \mathrm{c} \\
\end{array}$ & $* * *$ & nd & nd & nd & na \\
\hline kaempferol-3-O-rutinoside & $\begin{array}{l}270 \pm \\
9.55 \mathrm{c}\end{array}$ & $\begin{array}{l}313 \pm \\
4.63 \mathrm{~b}\end{array}$ & $\begin{array}{l}408 \pm \\
9.77 \mathrm{a} \\
\end{array}$ & $* * *$ & $\begin{array}{l}4.48 \pm \\
0.03 \mathrm{~b}\end{array}$ & $\begin{array}{l}3.23 \pm \\
0.14 \mathrm{c} \\
\end{array}$ & $\begin{array}{l}5.13 \pm \\
0.18 \mathrm{a} \\
\end{array}$ & $* * *$ & $\begin{array}{l}15.1 \pm \\
0.66 \mathrm{a} \\
\end{array}$ & $\begin{array}{l}10.3 \pm \\
0.34 \mathrm{~b}\end{array}$ & $\begin{array}{l}10.1 \pm \\
0.60 \mathrm{~b}\end{array}$ & $* * *$ & $\begin{array}{l}0.10 \pm \\
0.01 \mathrm{c} \\
\end{array}$ & $\begin{array}{l}0.22 \pm \\
0.01 \mathrm{~b} \\
\end{array}$ & $\begin{array}{l}0.28 \pm \\
0.02 \mathrm{a}\end{array}$ & $* * *$ \\
\hline quercetin-rhamnoside & $\begin{array}{l}0.19 \pm \\
0.02 \mathrm{a}\end{array}$ & $\begin{array}{c}0.16 \pm \\
0.02 \mathrm{ab}\end{array}$ & $\begin{array}{l}0.11 \pm \\
0.00 \mathrm{~b}\end{array}$ & * & $\begin{array}{c}52.1 \pm \\
2.81\end{array}$ & $\begin{array}{c}96.7 \pm \\
3.79\end{array}$ & $\begin{array}{c}148 \pm \\
112\end{array}$ & ns & $\begin{array}{l}102 \pm \\
9.49 \mathrm{a}\end{array}$ & $\begin{array}{l}68.9 \pm \\
1.16 \mathrm{~b}\end{array}$ & $\begin{array}{l}65.0 \pm \\
3.54 \mathrm{~b}\end{array}$ & $* *$ & $\begin{array}{l}0.15 \pm \\
0.01 \mathrm{c} \\
\end{array}$ & $\begin{array}{l}0.25 \pm \\
0.02 \mathrm{~b}\end{array}$ & $\begin{array}{l}0.33 \pm \\
0.01 \mathrm{a}\end{array}$ & $* * *$ \\
\hline luteolin-malonil-hexose & $\begin{array}{c}0.96 \pm \\
0.08 \\
\end{array}$ & $\begin{array}{c}1.04 \pm \\
0.11 \\
\end{array}$ & $\begin{array}{c}1.05 \pm \\
0.10 \\
\end{array}$ & ns & nd & nd & nd & na & nd & nd & nd & na & $\begin{array}{l}0.83 \pm \\
0.10 \mathrm{~b}\end{array}$ & $\begin{array}{l}0.91 \pm \\
0.05 \mathrm{~b}\end{array}$ & $\begin{array}{l}1.15 \pm \\
0.03 \mathrm{a} \\
\end{array}$ & * \\
\hline apigenin-7-rhamnoside-4-rutinoside & nd & nd & nd & na & nd & nd & nd & na & nd & nd & nd & na & $\begin{array}{r}7.12 \pm \\
0.36 \mathrm{c} \\
\end{array}$ & $\begin{array}{r}16.1 \pm \\
0.15 \mathrm{a} \\
\end{array}$ & $\begin{array}{l}13.2 \pm \\
0.17 \mathrm{~b}\end{array}$ & $* * *$ \\
\hline apigenin-7-O-glucoside & $\begin{array}{c}0.05 \pm \\
0.01\end{array}$ & $\begin{array}{c}0.06 \pm \\
0.01 \\
\end{array}$ & $\begin{array}{c}0.05 \pm \\
0.00 \\
\end{array}$ & ns & $\begin{array}{l}31.6 \pm \\
0.27 \mathrm{~b}\end{array}$ & $\begin{array}{l}46.9 \pm \\
2.36 \mathrm{a} \\
\end{array}$ & $\begin{array}{r}21.2 \pm \\
0.18 \mathrm{c} \\
\end{array}$ & $* * *$ & $\begin{array}{l}5.71 \pm \\
0.43 \mathrm{a} \\
\end{array}$ & $\begin{array}{l}3.20 \pm \\
0.12 \mathrm{~b}\end{array}$ & $\begin{array}{l}2.96 \pm \\
0.11 \mathrm{~b}\end{array}$ & $* * *$ & $\begin{array}{c}0.10 \pm \\
0.01 \\
\end{array}$ & $\begin{array}{c}0.10 \pm \\
0.01 \\
\end{array}$ & $\begin{array}{c}0.08 \pm \\
0.01 \\
\end{array}$ & ns \\
\hline Total polyphenols & $\begin{array}{c}9311 \pm \\
385 \mathrm{~b}\end{array}$ & $\begin{array}{c}10154 \\
\pm 311 \\
\text { ab }\end{array}$ & $\begin{array}{c}11246 \\
\pm 402 \mathrm{a}\end{array}$ & * & $\begin{array}{c}12255 \\
\pm 818 \mathrm{~b}\end{array}$ & $\begin{array}{c}16154 \\
\pm 113 \mathrm{a}\end{array}$ & $\begin{array}{c}12683 \\
\pm 199 \mathrm{~b}\end{array}$ & $* *$ & $\begin{array}{c}12717 \\
\pm 489 \mathrm{a}\end{array}$ & $\begin{array}{c}9999 \pm \\
273 \mathrm{~b}\end{array}$ & $\begin{array}{c}9774 \pm \\
201 \mathrm{~b}\end{array}$ & ** & $\begin{array}{l}441 \pm \\
21 \mathrm{~b}\end{array}$ & $\begin{array}{c}481 \pm \\
26 \mathrm{~b}\end{array}$ & $\begin{array}{c}858 \pm 8 \\
a\end{array}$ & $* * *$ \\
\hline
\end{tabular}

$\mathrm{ns}, * * * * * * *$ Non-significant or significant at $p \leq 0.05,0.01$, and 0.001 , respectively. Different letters within each column indicate significant mean differences within each genotype according

to Duncan's multiple range tests $(p \leq 0.05)$. All data are expressed as mean $\pm \mathrm{SE}, n=3$. nd not detected, na not available. 
In green basil, the content of caffeic acid hexoside, luteolin-7-O-glucoside, feruloyl quinic acid, and cirsiliol was higher than the control at both Se doses, while cichoric acid, chlorogenic acid, caffeic acid, rosmarinic acid, ferulic acid, and apigenin-7-O-glucoside increased only at the lowest Se dose (Table 4). On the contrary, in purple basil, a reduction of almost all the detected phenols was found in both Se treatments with respect to the control (Table 4). The content of phenolic acids varied according to the genotype and the Se dose in a specific way. In coriander and tatsoi, our results are consistent with what was found by D'amato et al. [49], which reported a rise in phenolic compounds in rice sprouts as the applied Se dose increased. Likewise, Se treatments in the range $0.25-0.50 \mathrm{mg}$ $\mathrm{L}^{-1}$ (3.2-6.4 $\mu \mathrm{M}$ Se) were shown to increase the total phenol content in wheat microgreen extract [10]. Regarding basil, in mature plants fertigated with a nutrient solution enriched with sodium selenate (2, 5, and $10 \mu \mathrm{M}$ Se), Skrypnik et al. [26] found a rise in the total phenolic compound content as the Se dose increased. These findings are in agreement with our results on green basil but in contrast with what was found on purple basil microgreens. Selenium induces abiotic stress similar to that caused by other heavy metals. Se-biofortified plants react to the presence of this element by activating the phenylpropanoid pathway [79], which results in the production of phenolic compounds in order to improve ROS scavenging [80]. However, polyphenolic acids, as well as the total content of phenolic compounds, can increase or decrease depending on the Se treatment, plant growth stage, and plant species $[16,49]$.

\section{Conclusions}

Nowadays, malnutrition still affects large portions of the world and many countries have recently resorted to biofortification programs to obtain micronutrient-enriched foods to enhance human nutrition and health. Microgreens represent an emerging class of functional foods with immense potential to improve the human diet and address nutritional deficiencies. In the present study, we proposed the Se biofortification of four microgreen genotypes to produce Se-enriched foods with a high nutraceutical profile in a very simple soilless cultivation system. Our results indicated that selenium doses up to $16 \mu \mathrm{M}$ significantly enhanced the content of this element without depressing the yield, thus demonstrating the effectiveness of Se biofortification of microgreens. In coriander and tatsoi, the application of $16 \mu \mathrm{M}$ Se triggered a substantial increase in the total phenols content $(21 \%$ and $95 \%$, respectively) and boosted fresh yield by $44 \%$ and $18 \%$, respectively. Instead, in green and purple basil, Se doses of $8 \mu \mathrm{M}$ significantly improved the lutein concentration (7\% and 19\%, respectively) and the overall macroelements content, as well as the total amount of polyphenols (32\%) in the green pigmented cultivar. Regarding the effectiveness of Se biofortification, a fresh portion (10 $\mathrm{g} \mathrm{fw}) \mathrm{of}$ coriander and tatsoi microgreens treated with the dose of $16 \mu \mathrm{M}$ Se satisfied $61 \%$ and $90 \%$ of the RDA-Se, respectively, whereas the $8 \mu \mathrm{M}$ Se application was enough to supply $133 \%$ and $83 \%$ of the RDA-Se by consuming a fresh portion of basil-enriched microgreens of green and purple cultivars, respectively. In conclusion, the optimal Se dose that ensures the effectiveness of Se biofortification and additionally enhances the bioactive content of microgreens is $16 \mu \mathrm{M}$ in coriander and tatsoi and 8 $\mu \mathrm{M}$ in green and purple basil. The potential success of vegetable biofortification is based on the right selection of target crops and on the optimization and standardization of the cultivation systems. These are the prerequisites that guarantee sustainability in the production of micronutrient-enriched, safe to eat, and high-quality food that meets the RDA standards for the targeted element, while being easy to introduce into the diet of different regions of the world.

Author Contributions: Conceptualization, Y.R.; methodology, C.E.-N., A.P. and M.G.; software, C.E.-N, A.P., G.A.S. and M.G.; validation, C.E.-N., A.P. and M.G. and A.Z.; A.Z. and G.G..; investigation, A.P., C.-E.-N., G.G., M.C.K., M.G., G.A.S., A.Z., A.R., S.D.P.; resources, Y.R.; data curation, A.P. and G.G.; writing-original draft preparation, A.P. and Y.R.; writing-review and editing, A.P., M.K. and Y.R.; visualization, A.R. and S.D.P.; supervision, A.P., A.Z., M.C.K., A.R., S.D.P. and Y.R.; project administration, Y.R.; funding acquisition, S.D.P. and Y.R. All authors have read and agreed to the published version of the manuscript. 
Funding: The authors acknowledge the project In-situ REsource Bio-Utilization for life Support system (ReBUS), unique project code (CUP) F74I16000000005 financed by the Italian Space Agency. The work was supported by the Italian Space Agency through the project "Microgreens × Microgravity (MICRO×2)".

Conflicts of Interest: The authors declare no conflict of interest.

\section{References}

1. Di Gioia, F.; De Bellis, P.; Mininni, C.; Santamaria, P.; Serio, F. Physicochemical, agronomical and microbiological evaluation of alternative growing media for the production of rapini (Brassica rapa L.) microgreens. J. Sci. Food Agric. 2017, 97, 1212-1219. [CrossRef] [PubMed]

2. Kyriacou, M.C.; El-Nakhel, C.; Graziani, G.; Pannico, A.; Soteriou, G.A.; Giordano, M. Functional quality in novel food sources: Genotypic variation in the nutritive and phytochemical composition of thirteen microgreens species. Food Chem. 2019, 277, 107-118. [CrossRef] [PubMed]

3. Sun, J.; Xiao, Z.; Lin, L.Z.; Lester, G.E.; Wang, Q.; Harnly, J.M.; Chen, P. Profiling polyphenols in five Brassica species microgreens by UHPLC-PDA-ESI/HRMSn. J. Agric. Food Sci. 2013, 61, 10960-10970. [CrossRef] [PubMed]

4. Kyriacou, M.C.; Rouphael, Y.; Di Gioia, F.; Kyratzis, A.; Serio, F.; Renna, M.; De Pascale, S.; Santamaria, P. Micro-scale vegetable production and the rise of microgreens. Trends Food Sci. Technol. 2016, 57, 103-115. [CrossRef]

5. Yadav, L.P.; Koley, T.K.; Tripathi, A.; Singh, S. Antioxidant potentiality and mineral content of summer season leafy greens: Comparison at mature and microgreen stages using chemometric. Agric. Res. 2019, 8, 165-175. [CrossRef]

6. Pinto, E.; Almeida, A.A.; Aguiar, A.A.; Ferreira, I.M.P.L.V.O. Comparison between the mineral profile and nitrate content of microgreens and mature lettuces. J. Food Comp. Anal. 2015, 37, 38-43. [CrossRef]

7. Kopppertcress. Available online: https://www.koppertcress.com/en/nieuws/koppert-cress-leading-the-waywith-new-educational-programme-on-microgreens (accessed on 20 December 2019).

8. Xiao, Z.; Lester, G.E.; Park, E.; Saftner, R.A.; Luo, Y.; Wang, Q. Evaluation and correlation of sensory attributes and chemical compositions of emerging fresh produce: Microgreens. Postharvest Biol. Technol. 2015, 110, 140-148. [CrossRef]

9. Puccinelli, M.; Malorgio, F.; Rosellini, I.; Pezzarossa, B. Production of selenium-biofortified microgreens from selenium-enriched seeds of basil. J. Sci. Food Agric. 2019, 99, 5601-5605. [CrossRef]

10. Islam, M.Z.; Park, B.J.; Kang, H.M.; Lee, Y.T. Influence of selenium biofortification on the bioactive compounds and antioxidant activity of wheat microgreen extract. Food Chem. 2020, 309, 125763. [CrossRef]

11. Rayman, M.P. The argument for increasing selenium intake. Proc. Nutr. Soc. 2002, 61, 203-215. [CrossRef] [PubMed]

12. Jones, G.D.; Droz, B.; Greve, P.; Gottschalk, P.; Poffet, D.; McGrath, S.P. Selenium deficiency risk predicted to increase under future climate change. Proc. Natl. Acad. Sci. USA 2017, 114, 2848-2853. [CrossRef] [PubMed]

13. Carvalho, S.M.; Vasconcelos, M.W. Producing more with less: Strategies and novel technologies for plant-based food biofortification. Food Res. Int. 2013, 54, 961-971. [CrossRef]

14. Rayman, M.P. The importance of selenium to human health. Lancet 2000, 356, 233-241. [CrossRef]

15. Finley, J.W. Proposed criteria for assessing the efficacy of cancer reduction by plant foods enriched in carotenoids, glucosinolates, polyphenols and selenocompounds. Ann. Bot. 2005, 95, 1075-1096. [CrossRef] [PubMed]

16. Malagoli, M.; Schiavon, M.; Dall'Acqua, S.; Pilon-Smits, E.A. Effects of selenium biofortification on crop nutritional quality. Front. Plant Sci. 2015, 6, 280. [CrossRef] [PubMed]

17. Johnson, L.J.; Meacham, S.L.; Kruskall, L.J. The antioxidants-vitamin C, vitamin E, selenium, and carotenoids. J. Agromed. 2003, 9, 65-82. [CrossRef]

18. Burk, R.F.; Norsworthy, B.K.; Hill, K.E.; Motley, A.K.; Byrne, D.W. Effects of chemical form of selenium on plasma biomarkers in a high-dose human supplementation trial. Cancer Epidemiol. Biomark. 2006, 15, 804-810. [CrossRef]

19. Finley, J.W. Increased intakes of selenium-enriched foods may benefit human health. J. Sci. Food Agric. 2007, 87, 1620-1629. [CrossRef] 
20. Pilon-Smits, E.A.; Quinn, C.F. Selenium metabolism in plants. In Cell Biology of Metals and Nutrients; Springer: Berlin/Heidelberg, Germany, 2010; pp. 225-241. [CrossRef]

21. Vatansever, R.; Ozyigit, I.I.; Filiz, E. Essential and beneficial trace elements in plants, and their transport in roots: A review. Appl. Biochem. Biotechnol. 2017, 181, 464-482. [CrossRef]

22. Chauhan, R.; Awasthi, S.; Srivastava, S.; Dwivedi, S.; Pilon-Smits, E.A.; Dhankher, O.P. Understanding selenium metabolism in plants and its role as a beneficial element. Crit. Rev. Environ. Sci. Technol. 2019, 49, 1937-1958. [CrossRef]

23. Hartikainen, H. Biogeochemistry of selenium and its impact on food chain quality and human health. J. Trace Elem. Med. Biol. 2005, 18, 309-318. [CrossRef] [PubMed]

24. Lyons, G.H.; Genc, Y.; Soole, K.M.; Stangoulis, J.C.R.; Liu, F.; Graham, R.D. Selenium increases seed production in Brassica. Plant Soil 2009, 318, 73-80. [CrossRef]

25. Ardebili, Z.O.; Ardebili, N.O.; Jalili, S.; Safiallah, S. The modified qualities of basil plants by selenium and/or ascorbic acid. Turk. J. Bot. 2015, 39, 401-407. [CrossRef]

26. Skrypnik, L.; Novikova, A.; Tokupova, E. Improvement of phenolic compounds, essential oil content and antioxidant properties of sweet basil (Ocimum basilicum L.) depending on type and concentration of selenium application. Plants 2019, 8, 458. [CrossRef] [PubMed]

27. Dall'Acqua, S.; Ertani, A.; Pilon-Smits, E.A.; Fabrega-Prats, M.; Schiavon, M. Selenium biofortification differentially affects sulfur metabolism and accumulation of phytochemicals in two rocket species (Eruca Sativa Mill. and Diplotaxis Tenuifolia) grown in hydroponics. Plants 2019, 8, 68. [CrossRef] [PubMed]

28. Li, H.F.; McGrath, S.P.; Zhao, F.J. Selenium uptake, translocation and speciation in wheat supplied with selenate or selenite. New Phytol. 2008, 178, 92-102. [CrossRef]

29. Lyons, G.H.; Ortiz-Monasterio, I.; Stangoulis, J.; Graham, R. Selenium concentration in wheat grain: Is there sufficient genotypic variation to use in breeding? Plant Soil 2005, 269, 369-380. [CrossRef]

30. Hawrylak-Nowak, B. Comparative effects of selenite and selenate on growth and selenium accumulation in lettuce plants under hydroponic conditions. Plant Growth Regul. 2013, 70, 149-157. [CrossRef]

31. White, P.J. Selenium metabolism in plants. Biochim. Biophys. Acta (BBA)-Gen. Subj. 2018, 1862, $2333-2342$. [CrossRef]

32. Puccinelli, M.; Malorgio, F.; Rosellini, I.; Pezzarossa, B. Uptake and partitioning of selenium in basil (Ocimum basilicum L.) plants grown in hydroponics. Sci. Hortic. 2017, 225, 271-276. [CrossRef]

33. Rouphael, Y.; Kyriacou, M.C. Enhancing quality of fresh vegetables through salinity eustress and biofortification applications facilitated by soilless cultivation. Front. Plant Sci. 2018, 9, 1254. [CrossRef] [PubMed]

34. El-Nakhel, C.; Pannico, A.; Kyriacou, M.C.; Giordano, M.; De Pascale, S.; Rouphael, Y. Macronutrient deprivation eustress elicits differential secondary metabolites in red and green-pigmented butterhead lettuce grown in a closed soilless system. J. Sci. Food Agric. 2019, 99, 6962-6972. [CrossRef] [PubMed]

35. Lyons, G.H.; Stangoulis, J.C.; Graham, R.D. Exploiting micronutrient interaction to optimize biofortification programs: The case for inclusion of selenium and iodine in the HarvestPlus program. Nutr. Rev. 2004, 62, 247-252. [CrossRef] [PubMed]

36. Chen, L.; Yang, F.; Xu, J.; Hu, Y.; Hu, Q.; Zhang, Y. Determination of selenium concentration of rice in China and effect of fertilization of selenite and selenate on selenium content of rice. J. Agric. Food Chem. 2002, 50, 5128-5130. [CrossRef]

37. Hernández-Hernández, H.; Quiterio-Gutiérrez, T.; Cadenas-Pliego, G.; Ortega-Ortiz, H.; Hernández-Fuentes, A.D.; Cabrera de la Fuente, M.; Valdés-Reyna, V.; Juárez-Maldonado, A. Impact of selenium and copper nanoparticles on yield, antioxidant system, and fruit quality of tomato plants. Plants 2019, 8, 355. [CrossRef]

38. Turakainen, M.; Hartikainen, H.; Seppänen, M.M. Effects of selenium treatments on potato (Solanum tuberosum L.) growth and concentrations of soluble sugars and starch. J. Agric. Food Chem. 2004, 52, 5378-5382. [CrossRef]

39. Hermosillo-Cereceres, M.A.; Sanchez-Chavez, E.; Balandran-Quintana, R.R.; Mendoza-Wilson, A.M.; Guevara-Aguilar, A.; Munoz-Marquez, E. Ionome variation in bean plant growth under different Se forms and application rates. J. Food Agric. Environ. 2011, 9, 374-378. [CrossRef]

40. Jerše, A.; Maršić, N.K.; Kroflič, A.; Germ, M.; Šircelj, H.; Stibilj, V. Is foliar enrichment of pea plants with iodine and selenium appropriate for production of functional food? Food Chem. 2018, 267, 368-375. [CrossRef] 
41. Sabatino, L.; Ntatsi, G.; Iapichino, G.; D'Anna, F.; De Pasquale, C. Effect of selenium enrichment and type of application on yield, functional quality and mineral composition of curly endive grown in a hydroponic system. Agronomy 2019, 9, 207. [CrossRef]

42. Bachiega, P.; Salgado, J.M.; de Carvalho, J.E.; Ruiz, A.L.T.; Schwarz, K.; Tezotto, T.; Morzelle, M.C. Antioxidant and antiproliferative activities in different maturation stages of broccoli (Brassica oleracea Italica) biofortified with selenium. Food Chem. 2016, 190, 771-776. [CrossRef]

43. Pannico, A.; El Nakhel, C.; Kyriacou, M.C.; Giordano, M.; Stazi, S.R.; De Pascale, S.; Rouphael, Y. Combating micronutrient deficiency and enhancing food functional quality through selenium fortification of select lettuce genotypes grown in a closed soilless system. Front. Plant Sci. 2019, 10, 1495. [CrossRef] [PubMed]

44. Poldma, P.; Tonutare, T.; Viitak, A.; Luik, A.; Moor, U. Effect of selenium treatment on mineral nutrition, bulb size, and antioxidant properties of garlic (Allium sativum L.). J. Agric. Food Chem. 2011, 59, 5498-5503. [CrossRef] [PubMed]

45. Golubkina, N.; Zamana, S.; Seredin, T.; Poluboyarinov, P.; Sokolov, S.; Baranova, H.; Pietroantonio, L.; Caruso, G. Effect of selenium biofortification and beneficial microorganism inoculation on yield, quality and antioxidant properties of shallot bulbs. Plants 2019, 8, 102. [CrossRef] [PubMed]

46. Germ, M.; Stibilj, V.; Šircelj, H.; Jerše, A.; Kroflič, A.; Golob, A.; Maršić, N.K. Biofortification of common buckwheat microgreens and seeds with different forms of selenium and iodine. J. Sci. Food Agric. 2019, 99, 4353-4362. [CrossRef] [PubMed]

47. Volpe, M.G.; Nazzaro, M.; Di Stasio, M.; Siano, F.; Coppola, R.; De Marco, A. Content of micronutrients, mineral and trace elements in some Mediterranean spontaneous edible herbs. Chem. Cent. J. 2015, 9, 57. [CrossRef]

48. Iris. Integrated Risk Information System-Database; Environmental Protection Agency: Washington, DC, USA, 2011.

49. D'Amato, R.; Fontanella, M.C.; Falcinelli, B.; Beone, G.M.; Bravi, E.; Marconi, O. Selenium biofortification in rice (Oryza sativa L.) sprouting: Effects on Se yield and nutritional traits with focus on phenolic acid profile. J. Agric. Food Chem. 2018, 66, 4082-4090. [CrossRef]

50. Singh, M.; Singh, N.; Bhandari, D.K. Interaction of selenium and sulfur on the growth and chemical composition of raya. Soil Sci. 1980, 129, 238-244. [CrossRef]

51. Hartikainen, H.; Xue, T. The promotive effect of selenium on plant growth as triggered by ultraviolet irradiation. J. Environ. Qual. 1999, 28, 1372-1375. [CrossRef]

52. Saffaryazdi, A.; Lahouti, M.; Ganjeali, A.; Bayat, H. Impact of selenium supplementation on growth and selenium accumulation on spinach (Spinacia oleracea L.) plants. Not. Sci. Biol. 2012, 4, 95-100. [CrossRef]

53. Ramos, S.J.; Faquin, V.; Guilherme, L.R.G.; Castro, E.M.; Ávila, F.W.; Carvalho, G.S. Selenium biofortification and antioxidant activity in lettuce plants fed with selenate and selenite. Plant Soil Environ. 2010, 56, 584-588. [CrossRef]

54. Chauhan, R.; Awasthi, S.; Tripathi, P.; Mishra, S.; Dwivedi, S.; Niranjan, A.; Tripathi, R.D. Selenite modulates the level of phenolics and nutrient element to alleviate the toxicity of arsenite in rice (Oryza sativa L.). Ecotoxicol. Environ. Saf. 2017, 138, 47-55. [CrossRef] [PubMed]

55. Feng, R.; Wei, C.; Tu, S. The roles of selenium in protecting plants against abiotic stresses. Environ. Exp. Bot. 2013, 87, 58-68. [CrossRef]

56. Hartikainen, H.; Xue, T.; Piironen, V. Selenium as an anti-oxidant and pro-oxidant in ryegrass. Plant Soil 2000, 225, 193-200. [CrossRef]

57. Terry, N.; Zayed, A.M.; De Souza, M.P.; Tarun, A.S. Selenium in higher plants. Annu. Rev. Plant Biol. 2000, 51, 401-432. [CrossRef]

58. Colla, G.; Kim, H.J.; Kyriacou, M.C.; Rouphael, Y. Nitrate in fruits and vegetables. Sci. Hortic. 2018, 237, 221-238. [CrossRef]

59. Commission Regulation (EU) No 1258/2011. Amending Regulation (EC) No 1881/2006 as regards maximum levels for nitrates in foodstuffs. Off. J. Eur. Union 2011, 320, 15-17.

60. Rios, J.J.; Blasco, B.; Rosales, M.A.; Sanchez-Rodriguez, E.; Leyva, R.; Cervilla, L.M. Response of nitrogen metabolism in lettuce plants subjected to different doses and forms of selenium. J. Sci. Food Agric. 2010, 90, 1914-1919. [CrossRef]

61. Nowak, J.; Kaklewski, K.; Ligocki, M. Influence of selenium on oxidoreductive enzymes activity in soil and in plants. Soil Biol. Biochem. 2004, 36, 1553-1558. [CrossRef] 
62. Lee, S.J.; Kang, H.M.; Kim, I.S. Effect of sodium selenate supplied condition by fertigation on the growth and content of minerals, ascorbic acid, nitrate, and selenium of some western vegetables. J. Bio-Environ. Control 2008, 17, 43-50.

63. Ríos, J.J.; Blasco, B.; Cervilla, L.M.; Rubio-Wilhelmi, M.; Rosales, M.A.; Sanchez-Rodriguez, E. Nitrogen-use efficiency in relation to different forms and application rates of Se in lettuce plants. J. Plant Growth Regul. 2010, 29, 164-170. [CrossRef]

64. Gupta, U.C.; Gupta, S.C. Sources and deficiency diseases of mineral nutrients in human health and nutrition: A review. Pedosphere 2014, 24, 13-38. [CrossRef]

65. Xiao, Z.; Codling, E.E.; Luo, Y.; Nou, X.; Lester, G.E.; Wang, Q. Microgreens of Brassicaceae: Mineral composition and content of 30 varieties. J. Food Comp. Anal. 2016, 49, 87-93. [CrossRef]

66. Wu, L.; Huang, Z.Z. Selenium assimilation and nutrient element uptake in white clover and tall fescue under the influence of sulphate concentration and selenium tolerance of the plants. J. Exp. Bot. 1992, 43, 549-555. [CrossRef]

67. Rios, J.J.; Blasco, B.; Leyva, R.; Sanchez-Rodriguez, E.; Rubio-Wilhelmi, M.M.; Romero, L. Nutritional balance changes in lettuce plant grown under different doses and forms of selenium. J. Plant Nutr. 2013, 36, 1344-1354. [CrossRef]

68. Couto, E.; Boffetta, P.; Lagiou, P.; Ferrari, P.; Buckland, G.; Overvad, K. Mediterranean dietary pattern and cancer risk in the EPIC cohort. Br. J. Cancer 2011, 104, 1493-1499. [CrossRef]

69. Silva, V.M.; Boleta, E.H.M.; Martins, J.T.; Mendes dos Santos, F.L.; da Rocha Silva, A.C.; Alcock, T.D. Agronomic biofortification of cowpea with selenium: Effects of selenate and selenite applications on selenium and phytate concentrations in seeds. J. Sci. Food Agric. 2019, 29, 371-379. [CrossRef]

70. Young, A.J.; Lowe, G.M. Antioxidant and prooxidant properties of carotenoids. Arch. Biochem. Biophys. 2001, 385, 20-27. [CrossRef]

71. O’Neill, M.E.; Carroll, Y.; Corridan, B.; Olmedilla, B.; Granado, F.; Blanco, I.; Van den Berg, H.; Hininger, I.; Rousell, A.M.; Chopra, M.; et al. A European carotenoid database to assess carotenoid intakes and its use in a five-country comparative study. Br. J. Nutr. 2001, 85, 499-507. [CrossRef]

72. Rapp, L.M.; Maple, S.S.; Choi, J.H. Lutein and zeaxanthin concentrations in rod outer segment membranes from perifoveal and peripheral human retina. Investig. Ophthalmol. Vis. Sci. 2000, 41, 1200-1209.

73. Naves, M.M.V.; Moreno, F.S. $\beta$-carotene and cancer chemoprevention: From epidemiological associations to cellular mechanisms of action. Nutr. Res. 1998, 18, 1807-1824. [CrossRef]

74. Jiang, C.; Zu, C.; Shen, J.; Shao, F.; Li, T. Effects of selenium on the growth and photosynthetic characteristics of flue-cured tobacco (Nicotiana tabacum L.). Acta Soc. Bot. Pol. 2015, 84, 71-77. [CrossRef]

75. Akladious, S.A. Influence of different soaking times with selenium on growth, metabolic activities of wheat seedlings under low temperature stress. Afr. J. Biotechnol. 2012, 11, 14792-14804.

76. Sams, C.E.; Panthee, D.R.; Charron, C.S.; Kopsell, D.A.; Yuan, J.S. Selenium regulates gene expression for glucosinolate and carotenoid biosynthesis in Arabidopsis. J. Am. Soc Hortic. Sci. 2011, 136, 23-34. [CrossRef]

77. El-Zaeddi, H.; Calín-Sánchez, Á.; Nowicka, P.; Martínez-Tomé, J.; Noguera-Artiaga, L.; Burló, F.; Wojdyło, A.; Carbonell-Barrachina, Á.A. Preharvest treatments with malic, oxalic, and acetylsalicylic acids affect the phenolic composition and antioxidant capacity of coriander, dill and parsley. Food Chem. 2017, 226, 179-186. [CrossRef] [PubMed]

78. Flanigan, P.M.; Niemeyer, E.D. Effect of cultivar on phenolic levels, anthocyanin composition, and antioxidant properties in purple basil (Ocimum basilicum L.). Food Chem. 2014, 164, 518-526. [CrossRef] [PubMed]

79. Wang, G.; Wu, L.; Zhang, H.; Wu, W.; Zhang, M.; Li, X. Regulation of the phenylpropanoid pathway: A mechanism of selenium tolerance in peanut (Arachis hypogaea L.) seedlings. J. Agric. Food Chem. 2016, 64, 3626-3635. [CrossRef] [PubMed]

80. Ríos, J.J.; Blasco, B.; Cervilla, L.M.; Rubio-Wilhelmi, M.M.; Ruiz, J.M.; Romero, L. Regulation of sulphur assimilation in lettuce plants in the presence of selenium. Plant Growth Regul. 2008, 56, 43. [CrossRef]

(C) 2020 by the authors. Licensee MDPI, Basel, Switzerland. This article is an open access article distributed under the terms and conditions of the Creative Commons Attribution (CC BY) license (http://creativecommons.org/licenses/by/4.0/). 